\title{
Molecular distribution and stable carbon isotopic compositions of dicarboxylic acids and related SOA from biogenic sources in the summertime atmosphere of Mt. Tai in the North China Plain
}

\author{
Jingjing Meng ${ }^{1,3}$, Gehui Wang ${ }^{2,3,4}$, Zhanfang Hou ${ }^{1,3}$, Xiaodi Liu ${ }^{1}$, Benjie Wei ${ }^{1}$, Can Wu ${ }^{3}$, Cong Cao $^{3}$, Jiayuan Wang ${ }^{3}$, \\ Jianjun $\mathrm{Li}^{3}$, Junji $\mathrm{Cao}^{3}$, Erxun Zhang ${ }^{1}$, Jie Dong ${ }^{1}$, Jiazhen Liu ${ }^{1}$, Shuangshuang $\mathrm{Ge}^{2}$, and Yuning Xie ${ }^{2}$ \\ ${ }^{1}$ School of Environment and Planning, Liaocheng University, Liaocheng 252000, China \\ ${ }^{2}$ Key Laboratory of Geographic Information Science of the Ministry of Education, School of Geographic Sciences, \\ East China Normal University, Shanghai 200062, China \\ ${ }^{3}$ State Key Laboratory of Loess and Quaternary Geology, Key Lab of Aerosol Chemistry and Physics, \\ Institute of Earth Environment, Chinese Academy of Sciences, Xi' an 710075, China \\ ${ }^{4}$ School of Human Settlements and Civil Engineering, Xi' an Jiaotong University, Xi' an 710049, China
}

Correspondence: Gehui Wang (wanggh@ieecas.cn, ghwang@geo.ecnu.edu.cn)

Received: 12 March 2018 - Discussion started: 12 April 2018

Revised: 31 August 2018 - Accepted: 21 September 2018 - Published: 19 October 2018

\begin{abstract}
Molecular distributions and stable carbon isotopic $\left(\delta^{13} \mathrm{C}\right.$ values) compositions of dicarboxylic acids and related secondary organic aerosols (SOA) in $\mathrm{PM}_{2.5}$ aerosols collected on a day/night basis at the summit of Mt. Tai ( $1534 \mathrm{~m}$ a.s.l.) in the summer of 2016 were analyzed to investigate the sources and photochemical aging process of organic aerosols in the forested highland region of the North China Plain. The molecular distributions of dicarboxylic acids and related SOA are characterized by the dominance of oxalic acid $\left(\mathrm{C}_{2}\right)$, followed by malonic $\left(\mathrm{C}_{3}\right)$, succinic $\left(\mathrm{C}_{4}\right)$ and azelaic $\left(\mathrm{C}_{9}\right)$ acids. The concentration ratios of $\mathrm{C}_{2} / \mathrm{C}_{4}$, diacid-C / OC and $\mathrm{C}_{2}$ / total diacids are larger in the daytime than in the nighttime, suggesting that the daytime aerosols are more photochemically aged than those in the nighttime due to the higher temperature and stronger solar radiation. Both ratios of $\mathrm{C}_{2} / \mathrm{C}_{4}\left(R^{2}>0.5\right)$ and $\mathrm{C}_{3} / \mathrm{C}_{4}\left(R^{2}>0.5\right)$ correlated strongly with the ambient temperatures, indicating that SOA in the mountaintop atmosphere are mainly derived from the photochemical oxidation of local emissions rather than long-range transport. The mass ratios of azelaic acid to adipic acid $\left(\mathrm{C}_{9} / \mathrm{C}_{6}\right)$, azelaic acid to phthalic aid $\left(\mathrm{C}_{9} / \mathrm{Ph}\right)$ and glyoxal to methylglyoxal (Gly / mGly) and the strong linear correlations of major dicarboxylic acids and related SOA (i.e., $\mathrm{C}_{2}, \mathrm{C}_{3}, \mathrm{C}_{4}, \omega \mathrm{C}_{2}$, Pyr, Gly and mGly) with biogenic precursors (SOA tracers derived from isoprene, $\alpha / \beta$-pinene and $\beta$-caryophyllene) further suggest that
\end{abstract}

aerosols in this region are mainly originated from biogenic sources (i.e., tree emissions).

$\mathrm{C}_{2}$ concentrations correlated well with aerosol $\mathrm{pH}$, indicating that particle acidity favors the organic acid formation. The stable carbon isotopic compositions $\left(\delta^{13} \mathrm{C}\right)$ of the dicarboxylic acids are higher in the daytime than in the nighttime, with the highest value $\left(-16.5 \pm 1.9 \%\right.$ ) found for $\mathrm{C}_{2}$ and the lowest value $\left(-25.2 \pm 2.7 \%\right.$ o found for $\mathrm{C}_{9}$. An increase in $\delta^{13} \mathrm{C}$ values of $\mathrm{C}_{2}$ along with increases in $\mathrm{C}_{2} / \mathrm{Gly}$ and $\mathrm{C}_{2} /$ mGly ratios was observed, largely due to the isotopic fractionation effect during the precursor oxidation process.

\section{Introduction}

Secondary organic aerosols (SOA) account for a substantial fraction $(20 \%-90 \%)$ of the total $\mathrm{PM}_{2.5}$ mass in the troposphere, of which up to $80 \%$ are water-soluble (Hallquist et al., 2009; Kroll and Seinfeld, 2008). Due to the low vapor pressures and high hygroscopicity (approximately less than $10^{-7} \mathrm{~Pa}$ ) (Bilde et al., 2015; Ehn et al., 2014), dicarboxylic acids and related compounds are ubiquitously found in atmospheric water and particles (Kawamura and Bikkina, 2016; Sorooshian et al., 2007a). Because of the water-soluble and hygroscopic properties, dicarboxylic acids and related com- 
pounds play important roles in atmospheric aqueous chemistry and influence radiative forcing of aerosols by acting as cloud condensation nuclei (CCN) (Hoque et al., 2017; Wang et al., 2012, 2016; Zhang et al., 2016).

Although they can be emitted directly from sources such as incomplete combustion of fossil fuels (Kawamura and Kaplan, 1987) and biomass burning (Kawamura et al., 2013a, b; Narukawa et al., 1999), atmospheric dicarboxylic acids and related compounds are largely produced by photochemical oxidation of unsaturated fatty acids, PAHs (Kawamura et al., 1996), cyclic alkanes and other compounds (Kawamura and Usukura, 1993). Oxalic acid $\left(\mathrm{C}_{2}\right)$ is the smallest and the most abundant dicarboxylic acid (Wang et al., 2009, 2015). Modeling studies and cloud measurements have suggested that $\mathrm{C}_{2}$ is largely produced from aqueous-phase oxidation of less oxygenated organic precursors such as glyoxal (Gly), methyglyoxal (mGly) and pyruvic acid (Pyr) in clouds or wet aerosols and the photochemical breakdown of longer chain dicarboxylic acids (Wang et al., 2012, 2015).

There is a growing consensus on highlighting the significance of oxalic acid and related SOA formation from the photochemical oxidation of anthropogenic/biogenic volatile organic compounds (VOCs) via the aqueous phase in clouds or aqueous aerosol from many field observations and laboratory experiments as well as modeling studies (Bikkina et al., 2017; Cheng et al., 2017; Ervens et al., 2014; Fu et al., 2008; Lim et al., 2005; Miyazaki et al., 2009; Mochizuki et al., 2017). A ubiquitous layer of dicarboxylic acids was found above the clouds by aircraft measurements in the USA, indicating that organic acids are important $\mathrm{CCN}$ in the free troposphere (Sorooshian et al., 2007a, b). Compared to the aerosols in lowland areas, alpine aerosols have a more significant influence on cloud formation because they are more accessible to clouds due to the higher elevation. Mt. Tai is an isolated peak located in the center of the North China Plain, one of the regions with the worst air pollution in the world (Wang et al., 2009; Yang et al., 2017). A few studies have been conducted to investigate the molecular compositions, sources and formation mechanisms of SOA including dicarboxylic acids at Mt. Tai, but most of them were performed in May and June and mainly focused on the impact of anthropogenic activities such as field burning of wheat straw (Kawamura et al., 2013a, b; Zhu et al., 2018), while very little information on dicarboxylic acids and related SOA at Mt. Tai during the typical summertime season (i.e., July and August) is available when the emission of biogenic volatile organic compounds (BVOCs) is dominant. A 3-D model simulation shows that about $79 \%$ of oxalic acid in the global atmosphere is originated from the oxidation of natural vegetation emissions (Myriokefalitakis et al., 2011), suggesting the dominant contribution of BVOCs to the global SOA loading. Therefore, it is necessary to investigate the abundances, compositions and formation mechanisms of oxalic acid and related SOA when vegetation emission is dominant, especially in the forested highland region where aerosols are more accessible to clouds due to higher elevation.

Compound-specific stable carbon isotope analysis is a powerful tool to provide important information of the sources and atmospheric processing of organic aerosols because the isotopic fractionation of carbon occurs upon chemical reactions or phase transfer (Pavuluri and Kawamura, 2016; Zhang et al., 2016). Analyses of stable carbon isotope ratios $\left(\delta^{13} \mathrm{C}\right)$ of dicarboxylic acids and related SOA can be effectively applied to assess the photochemical aging level and relative contributions of primary emissions to aerosols in the atmosphere (Zhao et al., 2018). To the best of our knowledge, characteristics of the stable carbon isotopic compositions of dicarboxylic acids and related SOA in mountainous regions have not been investigated before. The current work will, for the first time, report the stable carbon isotopic compositions of dicarboxylic acids and related compounds in a mountainous area, which are very helpful for improving our understanding on the sources, formation mechanisms and atmospheric behavior of SOA. In this study, we first investigated the diurnal variations in molecular distributions and stable carbon isotopic compositions of dicarboxylic acids and related compounds. Then we discussed the impact of temperature $(T)$, relative humidity $(\mathrm{RH})$, particle acidity $\left(\mathrm{pH}_{\mathrm{IS}}\right)$, liquid water content (LWC) and $\mathrm{O}_{3}$ concentration on oxalic acid and related SOA to explore their sources and formation mechanisms in the forested highland region of the North China Plain.

\section{Experimental section}

\subsection{Aerosol sampling}

$\mathrm{PM}_{2.5}$ samples were collected at the Meteorological Observation Station of Mt. Tai, which is located at the summit of Mt. Tai $\left(36.25^{\circ} \mathrm{N}, 117.10^{\circ} \mathrm{E} ; 1534 \mathrm{~m}\right.$ a.s.l.) in the North China Plain (Fig. 1). The sampling site was located about $1 \mathrm{~km}$ to the north of the peak, with an altitude of $1465 \mathrm{~m}$ a.s.l., and there is little anthropogenic emission nearby. About $80 \%$ of the mountainous land is covered by vegetation known to comprise 989 species, which is densely wooded in summer (Fu et al., 2010). $\mathrm{PM}_{2.5}$ samples were collected from 20 July to 20 August 2016, each lasting $12 \mathrm{~h}$ on a day/night basis, using a mid-volume air sampler (KC-120H, Qingdao Laoshan Company, China) equipped with prebaked $\left(450^{\circ} \mathrm{C}\right.$, $8 \mathrm{~h}$ ) quartz fiber filters (Whatman, USA) at an airflow rate of $100 \mathrm{~L} \mathrm{~min}^{-1}$. The daytime samples were collected from 08:00 to 20:00, while nighttime samples were collected from 20:00 to 08:00 of the next day. Field blank samples were also collected by mounting the blank filter onto the sampler for 15 min without sucking any air before and after the campaign. A total of 57 samples (daytime: 28; nighttime: 29) were collected during the campaign. After sampling, each filter was sealed in an aluminum foil bag and stored at $-20^{\circ} \mathrm{C}$ 


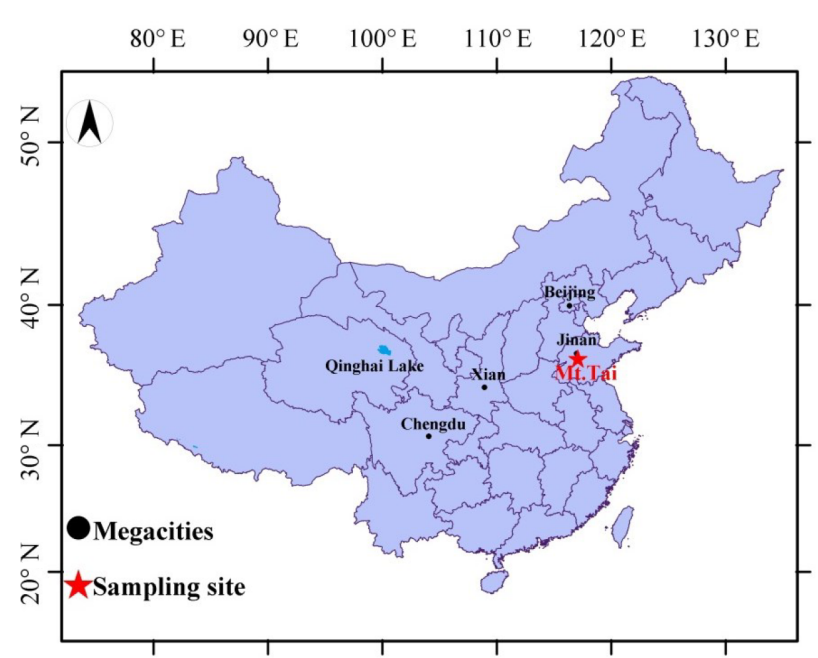

Figure 1. Location of the sampling site (Mt. Tai; $36.25^{\circ} \mathrm{N}$, $117.10^{\circ} \mathrm{E} ; 1534 \mathrm{~m}$ a.s.1.).

prior to laboratory analyses. Moreover, the concentration of ozone was simultaneously monitored at the site by a UV absorption analyzer (Model 49C, Thermo Electron Corporation).

\subsection{Chemical analyses}

\subsubsection{Sample extraction, derivatization, gas chromatograph-mass spectrometer (GC/MS) and gas chromatograph-flame ionization detector (GC/FID) quantification}

Dicarboxylic acids, ketocarboxylic acids and $\alpha$-dicarbonyls in $\mathrm{PM}_{2.5}$ were determined using the method described by previous studies (Kawamura et al., 1996; Meng et al., 2013, 2014). Briefly, one half of the filter was cut into pieces and extracted with pure Milli-Q water under ultrasonication three times each for $15 \mathrm{~min}$. The water extracts were concentrated to near dryness and then reacted with $14 \% \mathrm{BF}_{3} / n$ butanol at $100^{\circ} \mathrm{C}$ for $1 \mathrm{~h}$ to form butyl esters/dibutoxy acetals. After derivatization, $n$-hexane was added and washed with pure water three times. Finally, the hexane layer was concentrated to $200 \mu \mathrm{L}$ and determined using a capillary gas chromatograph (Agilent GC 7890A) coupled with a split/splitless injector. The GC was equipped with a flame ionization detector (FID) and a fused silica capillary column (HP-5, $0.2 \mathrm{~mm} \times 25 \mathrm{~m}$, film thickness $0.5 \mu \mathrm{m}$ ). The GC oven temperature was programmed from $50(2 \mathrm{~min})$ to $120^{\circ} \mathrm{C}$ at $15^{\circ} \mathrm{Cmin}^{-1}$, and then to 300 at $5^{\circ} \mathrm{C} \mathrm{min}^{-1}$ with a final isothermal hold at $300^{\circ} \mathrm{C}$ for $16 \mathrm{~min}$. Peak identification was performed by comparing the $\mathrm{GC}$ retention time with that of authentic standards and confirmed by mass spectrum of the sample using a GC-MS. Recoveries of the target compounds were $80 \%$ for oxalic acid and $85 \%$ to $110 \%$ for other species. The target compounds in the field blank sam- ples were lower than $4 \%$ of those in the ambient samples. Data presented here were corrected for both field blanks and recoveries.

The analysis method of biogenic precursors has been reported elsewhere (Li et al., 2013). Briefly, one-quarter of the filter was cut and extracted with a mixture of dichloromethane and methanol $(2: 1, v / v)$ under ultrasonication. The extracts were concentrated using a rotary evaporator under vacuum conditions and then dried using pure nitrogen. After reaction with a mixture of N,O-bis-(trimethylsilyl) trifluoroacetamide (BSTFA) and pyridine $(5: 1, v / v)$ at $70^{\circ} \mathrm{C}$ for $3 \mathrm{~h}$, biogenic secondary organic aerosol (BSOA) tracers in the derivatized samples were determined using a GC-MS. These data were used in this study to explore the biogenic sources of dicarboxylic acids and related SOA.

\subsubsection{Stable carbon isotope composition of dicarboxylic acids and related SOA}

The stable carbon isotopic compositions $\left(\delta^{13} \mathrm{C}\right)$ of shorter chain dicarboxylic acids and related SOA were measured using the method developed by Kawamura and Watanabe (2004). Briefly, the $\delta^{13} \mathrm{C}$ values of the derivatized samples above were determined by gas chromatography-isotope ratio mass spectrometry (GC-IR-MS; Thermo Fisher, Delta $\mathrm{V}$ Advantage). The $\delta^{13} \mathrm{C}$ values were then calculated for free organic acids using an isotopic mass balance equation based on the measured $\delta^{13} \mathrm{C}$ values of derivatives and the derivatizing agent $\left(\mathrm{BF}_{3} / n\right.$-butanol) (Kawamura and Watanabe, 2004). To ensure the analytical error of the $\delta^{13} \mathrm{C}$ values less than $0.2 \%$, each sample was measured three times. The $\delta^{13} \mathrm{C}$ data reported here are averaged values of the triplicate measurements.

\subsubsection{Elemental carbon (EC), organic carbon (OC), inorganic ions, water-soluble organic carbon (WSOC), aerosol liquid water content (LWC) and in situ particle $\mathbf{p H}\left(\mathrm{pH}_{\mathrm{IS}}\right)$}

Briefly, EC and $\mathrm{OC}$ in the $\mathrm{PM}_{2.5}$ samples were determined by using a DRI Model 2001 Carbon Analyzer following the Interagency Monitoring of Protected Visual Environments (IMPROVE) thermal/optical reflectance (TOR) protocol (Chow et al., 2004). As for the measurement of inorganic ions and WSOC, an aliquot of the sample filters was extracted with $30 \mathrm{~mL}$ Milli-Q water using an ultrasonic bath three times each for $15 \mathrm{~min}$, and filtered through PTFE filters to remove insoluble particles and filter debris. The water extract was then separated into two parts. One part was analyzed for inorganic ions using an ion chromatograph (Dionex 600, Dionex, USA), and the other part of the water extract was used to determine WSOC using a Total Carbon Analyzer (TOC-L CPH, Shimadzu, Japan). As for the calculation of aerosol liquid water content (LWC) and in situ particle $\mathrm{pH}\left(\mathrm{pH}_{\mathrm{IS}}\right)$, the Aerosol Inorganic Model (AIM), using 
Table 1. Meteorological parameters and concentrations of inorganic ions, ozone, water soluble organic carbon (WSOC), organic carbon (OC), elemental carbon (EC), liquid water content (LWC) and in situ $\mathrm{pH}\left(\mathrm{pH}_{\mathrm{IS}}\right)$ of $\mathrm{PM}_{2.5}$ from Mt. Tai in the summer.

\begin{tabular}{|c|c|c|c|}
\hline & Daytime $(n=28)$ & Nighttime $(n=29)$ & Total $(n=57)$ \\
\hline \multicolumn{4}{|c|}{ Meteorological parameters and ozone } \\
\hline Temperature $\left({ }^{\circ} \mathrm{C}\right)$ & $23 \pm 2.9(17-28)$ & $19 \pm 2.9(12-25)$ & $21 \pm 3.6(12-28)$ \\
\hline Relative humidity (\%) & $92 \pm 5.0(80-98)$ & $77 \pm 8.2(65-93)$ & $84 \pm 9.9(65-98)$ \\
\hline $\mathrm{O}_{3}(\mathrm{ppb})$ & $32 \pm 16(7.8-61)$ & $22 \pm 12(6.0-48)$ & $27 \pm 15(6.0-61)$ \\
\hline \multicolumn{4}{|l|}{ Inorganic ions $\left(\mu \mathrm{g} \mathrm{m}^{-3}\right)$} \\
\hline $\mathrm{K}^{+}$ & $0.4 \pm 0.2(0.1-0.8)$ & $0.4 \pm 0.2(0.1-0.7)$ & $0.4 \pm 0.2(0.1-0.8)$ \\
\hline $\mathrm{Na}^{+}$ & $0.3 \pm 0.1(0.1-0.9)$ & $0.3 \pm 0.2(0.1-1.0)$ & $0.3 \pm 0.2(0.1-1.0)$ \\
\hline $\mathrm{NH}_{4}^{+}$ & $5.3 \pm 2.9(0.5-12)$ & $6.6 \pm 2.5(1.2-11)$ & $5.9 \pm 2.8(0.5-12)$ \\
\hline $\mathrm{Mg}^{2+}$ & $0.2 \pm 0.1(0-0.3)$ & $0.2 \pm 0.1(0.1-0.3)$ & $0.2 \pm 0.1(0-0.3)$ \\
\hline $\mathrm{Ca}^{2+}$ & $0.3 \pm 0.1(0-0.5)$ & $0.3 \pm 0.2(0.1-0.7)$ & $0.3 \pm 0.2(0-0.7)$ \\
\hline $\mathrm{NO}_{3}^{-}$ & $3.0 \pm 2.1(0.1-8.4)$ & $4.2 \pm 2.3(0.9-10)$ & $3.6 \pm 2.3(0.1-10)$ \\
\hline $\mathrm{SO}_{4}^{2-}$ & $13 \pm 6.9(3.0-33)$ & $9.6 \pm 3.7(2.9-18)$ & $12 \pm 5.8(2.9-33)$ \\
\hline Subtotal & $23 \pm 12(4.6-54)$ & $22 \pm 8.2(6.6-40)$ & $22 \pm 10(4.6-54)$ \\
\hline \multicolumn{4}{|l|}{ Other species $\left(\mu \mathrm{g} \mathrm{m}^{-3}\right)$} \\
\hline EC & $0.2 \pm 0.2(0-0.6)$ & $0.2 \pm 0.2(0-0.8)$ & $0.2 \pm 0.2(0-0.8)$ \\
\hline $\mathrm{OC}$ & $2.4 \pm 0.8(1.1-3.9)$ & $2.1 \pm 0.3(1.5-2.8)$ & $2.2 \pm 0.6(1.1-3.9)$ \\
\hline WSOC & $1.9 \pm 0.8(0.8-3.6)$ & $1.4 \pm 0.5(0.7-2.3)$ & $1.7 \pm 0.7(0.7-3.6)$ \\
\hline $\mathrm{pH}_{\mathrm{IS}}$ & $-0.04 \pm 0.5(-0.9-1.0)$ & $0.4 \pm 0.6(-1.0-1.2)$ & $0.2 \pm 0.6(-1.0-1.2)$ \\
\hline LWC & $94 \pm 100(10-313)$ & $75 \pm 69(6.3-199)$ & $84 \pm 86(6.3-313)$ \\
\hline $\mathrm{PM}_{2.5}$ & $38 \pm 19(6.1-83)$ & $36 \pm 14(11-66)$ & $37 \pm 16(6.1-83)$ \\
\hline
\end{tabular}

a $\mathrm{SO}_{4}^{2-}-\mathrm{NO}_{3}^{-}-\mathrm{NH}_{4}^{+}-\mathrm{H}^{+}$system (AIM-II), was employed (Li et al., 2013).

\section{Results and discussion}

\subsection{General description of chemical components at Mt. Tai}

The concentrations of dicarboxylic acids and related SOA, $\mathrm{EC}, \mathrm{OC}$, WSOC and inorganic ions in $\mathrm{PM}_{2.5}$ samples from Mt. Tai are summarized in Table 1. During the campaign, the height of the boundary layer at Mt. Tai was frequently reduced to $\sim 600 \mathrm{~m}$ at night, which kept the sampling site in the free troposphere at night. In contrast, the boundary layer extended far above the mountaintop during the daytime (Zhu et al., 2018). However, as a tracer of the combustion source, EC concentration is very low and shows a similar level in the day and night periods, suggesting that the impact of anthropogenic emissions from the lowland region on the mountaintop atmosphere is insignificant. As seen in Tables 1 and 2, the day and night data presented a large variability. To verify if the day and night aerosol chemistry is of significant difference, Student's $t$ test was performed for the day and night samples. As shown in Table S1, the concentrations and compositions of major species in $\mathrm{PM}_{2.5}$ between day and night show a $p$ value less than 0.005 , which clearly demonstrates that the abundances and compositions of the major species during the day and night are statistically different.

OC and WSOC in the $\mathrm{PM}_{2.5}$ samples in the daytime are similar to those in the nighttime (Table 1), but OC / EC and WSOC / OC ratios are around 1.4 times higher in the daytime than in the nighttime (Fig. 4), indicating an enhanced SOA production due to the stronger photochemical oxidation in the daytime rather than the changes in the planetary boundary layer heights (Hegde and Kawamura, 2012).

$\mathrm{SO}_{4}^{2-}$ is mainly produced from aqueous-phase oxidation of $\mathrm{SO}_{2}$, which is favored by higher temperature and humid conditions (Kundu et al., 2010; Zhang et al., 2015; Wang et al., 2018). Thus, the concentration and relative abundance of $\mathrm{SO}_{4}^{2-}$ are higher in the daytime than in the nighttime (Table 1 and Fig. S1). Conversely, the concentrations of $\mathrm{NO}_{3}^{-}$ and $\mathrm{NH}_{4}^{+}$present higher values in the nighttime compared to those in the daytime (Table 1). Particulate $\mathrm{NO}_{3}^{-}$is mainly formed via gas-phase oxidation of $\mathrm{NO}_{2}$ with $\mathrm{OH}$ radicals and subsequent partitioning into the aerosol phase with ammonia to form $\mathrm{NH}_{4} \mathrm{NO}_{3}$ (Pathak et al., 2009; Zhang et al., 2015). $\mathrm{NH}_{4} \mathrm{NO}_{3}$ is volatile and thus a lower temperature at night is favorable for $\mathrm{NH}_{4} \mathrm{NO}_{3}$ enriching in the aerosol phase (Bian et al., 2014), resulting in $\mathrm{NH}_{4} \mathrm{NO}_{3}$ being more abundant at night during the Mt. Tai observation period. As shown in Table 1, the remaining four kinds of cations $\left(\mathrm{K}^{+}\right.$, $\mathrm{Na}^{+}, \mathrm{Ca}^{2+}$ and $\mathrm{Mg}^{2+}$ ), which can be regarded as the key 
Table 2. Concentrations $\left(\mathrm{ng} \mathrm{m}^{-3}\right.$ ) of dicarboxylic acids, ketocarboxylic acids and $\alpha$-dicarbonyls of $\mathrm{PM}_{2.5}$ from Mt. Tai in the summer.

\begin{tabular}{|c|c|c|c|}
\hline Compounds & Daytime $(n=28)$ & Nighttime $(n=29)$ & Total $(n=57)$ \\
\hline \multicolumn{4}{|l|}{ Dicarboxylic acids } \\
\hline Oxalic, $\mathrm{C}_{2}$ & $272 \pm 190(11-623)$ & $156 \pm 105(34-415)$ & $213 \pm 162(11-623)$ \\
\hline Malonic, $\mathrm{C}_{3}$ & $49 \pm 30(4.0-101)$ & $31 \pm 17(7.4-69)$ & $40 \pm 26(4.0-101)$ \\
\hline Succinic, $\mathrm{C}_{4}$ & $30 \pm 23(2.0-83)$ & $24 \pm 16(4.7-67)$ & $27 \pm 20(2.0-83)$ \\
\hline Glutaric, $\mathrm{C}_{5}$ & $7.0 \pm 5.5(0.4-19)$ & $5.6 \pm 3.9(1.1-14)$ & $6.3 \pm 4.8(0.4-19)$ \\
\hline Adipic, $\mathrm{C}_{6}$ & $2.2 \pm 1.7(0.1-5.6)$ & $2.2 \pm 1.8(0.2-7.7)$ & $2.2 \pm 1.7(0.1-7.7)$ \\
\hline Pimelic, $\mathrm{C}_{7}$ & $3.0 \pm 1.9(0.3-7.3)$ & $2.9 \pm 1.3(0.3-6.1)$ & $3.0 \pm 1.6(0.3-7.3)$ \\
\hline Suberic, $\mathrm{C}_{8}$ & $4.3 \pm 2.2(0.9-9.0)$ & $3.8 \pm 2.8(0.4-13)$ & $4.0 \pm 2.5(0.4-13)$ \\
\hline Azelaic, $\mathrm{C}_{9}$ & $24 \pm 14(4.2-55)$ & $19 \pm 8.6(4.5-41)$ & $22 \pm 12(4.2-55)$ \\
\hline Sebacic, $\mathrm{C}_{10}$ & $5.9 \pm 4.3(0.1-14)$ & $5.6 \pm 2.7(0.7-11)$ & $5.8 \pm 3.6(0.1-14)$ \\
\hline Undecanedioic, $\mathrm{C}_{11}$ & $2.4 \pm 1.7(0.2-5.8)$ & $1.1 \pm 0.8(0-3.8)$ & $1.7 \pm 1.4(0-5.8)$ \\
\hline Methylmalonic, $\mathrm{iC}_{4}$ & $2.1 \pm 1.7(0.1-5.2)$ & $2.1 \pm 1.5(0-5.3)$ & $2.1 \pm 1.6(0-5.3)$ \\
\hline Methylsuccinic, $\mathrm{iC}_{5}$ & $2.7 \pm 2.0(0.1-7.1)$ & $2.2 \pm 1.7(0.2-6.1)$ & $2.4 \pm 1.8(0.1-7.1)$ \\
\hline Methylglutaric, $\mathrm{iC}_{6}$ & $2.6 \pm 2.1(0.5-9.1)$ & $2.3 \pm 1.9(0-9.0)$ & $2.5 \pm 2.0(0-9.1)$ \\
\hline Maleic, $\mathrm{M}$ & $2.0 \pm 1.2(0.1-4.3)$ & $3.0 \pm 2.0(0.7-8.2)$ & $2.5 \pm 1.7(0.1-8.2)$ \\
\hline Fumaric, F & $4.2 \pm 2.7(0.2-9.4)$ & $4.0 \pm 3.0(0.5-13)$ & $4.1 \pm 2.8(0.2-13)$ \\
\hline Methylmaleic, mM & $2.9 \pm 1.7(0.1-6.6)$ & $2.7 \pm 2.1(0.5-9.9)$ & $2.8 \pm 1.9(0.1-9.9)$ \\
\hline Phthalic, $\mathrm{Ph}$ & $3.0 \pm 1.5(0.6-5.6)$ & $3.3 \pm 2.3(0.7-11.2)$ & $3.2 \pm 1.9(0.6-11.2)$ \\
\hline Isophthalic, iPh & $1.6 \pm 1.0(0.1-3.3)$ & $1.3 \pm 0.8(0.2-3.5)$ & $1.4 \pm 0.9(0.1-3.5)$ \\
\hline Terephthalic, $\mathrm{tPh}$ & $1.9 \pm 1.3(0.1-5.0)$ & $2.4 \pm 1.5(0.1-6.1)$ & $2.2 \pm 1.4(0.1-6.1)$ \\
\hline Ketomalonic, $\mathrm{kC}_{3}$ & $2.6 \pm 1.5(0-5.8)$ & $2.7 \pm 1.5(0.5-6.4)$ & $2.7 \pm 1.5(0-6.4)$ \\
\hline Ketopimelic, $\mathrm{kC}_{7}$ & $3.6 \pm 2.8(0.2-9.3)$ & $3.9 \pm 2.6(0.2-12)$ & $3.7 \pm 2.7(0.2-12)$ \\
\hline Subtotal & $430 \pm 282(27-944)$ & $282 \pm 161(73-671)$ & $354 \pm 239(27-944)$ \\
\hline \multicolumn{4}{|l|}{ Ketocarboxylic acids } \\
\hline Pyruvic, Pyr & $14 \pm 8.8(1.4-28)$ & $11 \pm 5.5(2.2-23)$ & $12 \pm 7.4(1.4-28)$ \\
\hline Glyoxylic, $\omega \mathrm{C}_{2}$ & $18 \pm 12(0.9-38)$ & $15 \pm 9.5(3.5-35)$ & $16 \pm 11(0.9-38)$ \\
\hline 3-Oxopropanoic, $\omega \mathrm{C}_{3}$ & $4.0 \pm 2.7(0.1-7.7)$ & $4.1 \pm 2.2(0.5-8.3)$ & $4.1 \pm 2.4(0.1-8.3)$ \\
\hline 4-Oxobutanoic, $\omega \mathrm{C}_{4}$ & $2.9 \pm 1.9(0.2-6.8)$ & $2.5 \pm 1.7(0.6-7.1)$ & $2.7 \pm 1.8(0.2-7.1)$ \\
\hline 7-Oxoheptanoic, $\omega \mathrm{C} 7$ & $1.0 \pm 0.6(0-2.7)$ & $1.3 \pm 1.0(0.1-4.8)$ & $1.2 \pm 0.9(0.0-4.8)$ \\
\hline 8-Oxooctanoic, $\omega \mathrm{C}_{8}$ & $1.5 \pm 0.9(0.1-3.3)$ & $1.5 \pm 0.7(0.2-3.4)$ & $1.5 \pm 0.8(0.1-3.4)$ \\
\hline 9-Oxononanoic, $\omega \mathrm{C}_{9}$ & $2.0 \pm 1.4(0.1-4.4)$ & $1.8 \pm 1.1(0.2-4.3)$ & $1.9 \pm 1.3(0.1-4.4)$ \\
\hline Subtotal & $43 \pm 28(2.9-88)$ & $37 \pm 19(7.6-77)$ & $40 \pm 24(2.9-88)$ \\
\hline \multicolumn{4}{|l|}{$\alpha$-Dicarbonyls } \\
\hline Glyoxal, Gly & $3.1 \pm 1.8(0.3-6.0)$ & $4.6 \pm 2.6(0.4-12)$ & $3.8 \pm 2.3(0.3-12)$ \\
\hline Methyglyoxal, mGly & $16 \pm 9.5(1.8-33)$ & $22 \pm 15(1.4-62)$ & $19 \pm 13(1.4-62)$ \\
\hline Subtotal & $19 \pm 11(2.6-39)$ & $27 \pm 17(2.1-69)$ & $23 \pm 15(2.1-69)$ \\
\hline Total detected & $491 \pm 320(33-1060)$ & $346 \pm 194(96-807)$ & $417 \pm 271(33-1060)$ \\
\hline
\end{tabular}

markers of primary sources, did not exhibit significant diurnal variations, again suggesting that the effect of planetary boundary layer heights is minor. In this work, LWC and $\mathrm{pH}_{\mathrm{IS}}$ were calculated by using the AIM-II model because both species cannot be directly measured. LWC exhibits higher concentration $\left(94 \pm 100 \mathrm{\mu g} \mathrm{m}^{-3}\right)$ in the daytime than that $\left(75 \pm 69 \mu \mathrm{g} \mathrm{m}^{-3}\right)$ in the nighttime (Table 1). Aerosol LWC is controlled by the ambient relative humidity (Clegg et al., 1998) and the concentrations of inorganic salt (Fountoukis and Nenes, 2007). As shown in Table 1, the total concentration $\left(21.7 \pm 11.5 \mu \mathrm{g} \mathrm{m}^{-3}\right)$ of $\mathrm{SO}_{4}^{2-}, \mathrm{NO}_{3}^{-}$ and $\mathrm{NH}_{4}^{+}$during the daytime was almost equivalent to that $\left(20.4 \pm 8.2 \mu \mathrm{g} \mathrm{m}^{-3}\right)$ during the nighttime, but the relative humidity $(92 \pm 5.0 \%)$ in the daytime was higher than that in the nighttime $(77 \pm 8.2 \%)$. Therefore, the concentration of LWC in the daytime was higher than that in the nighttime. In contrast, $\mathrm{pH}_{\mathrm{IS}}$ shows a lower value $(-0.04 \pm 0.5)$ in the daytime compared to that $(0.4 \pm 0.6)$ in the nighttime (Table 1$)$, indicating the daytime aerosols are more acidic.

\subsection{Molecular distributions of dicarboxylic acids and related SOA}

A homologous series of dicarboxylic acids $\left(\mathrm{C}_{2}-\mathrm{C}_{11}\right)$, ketocarboxylic acids $\left(\omega \mathrm{C}_{2}-\omega \mathrm{C}_{9}\right.$ and pyruvic acid) and $\alpha$ - 


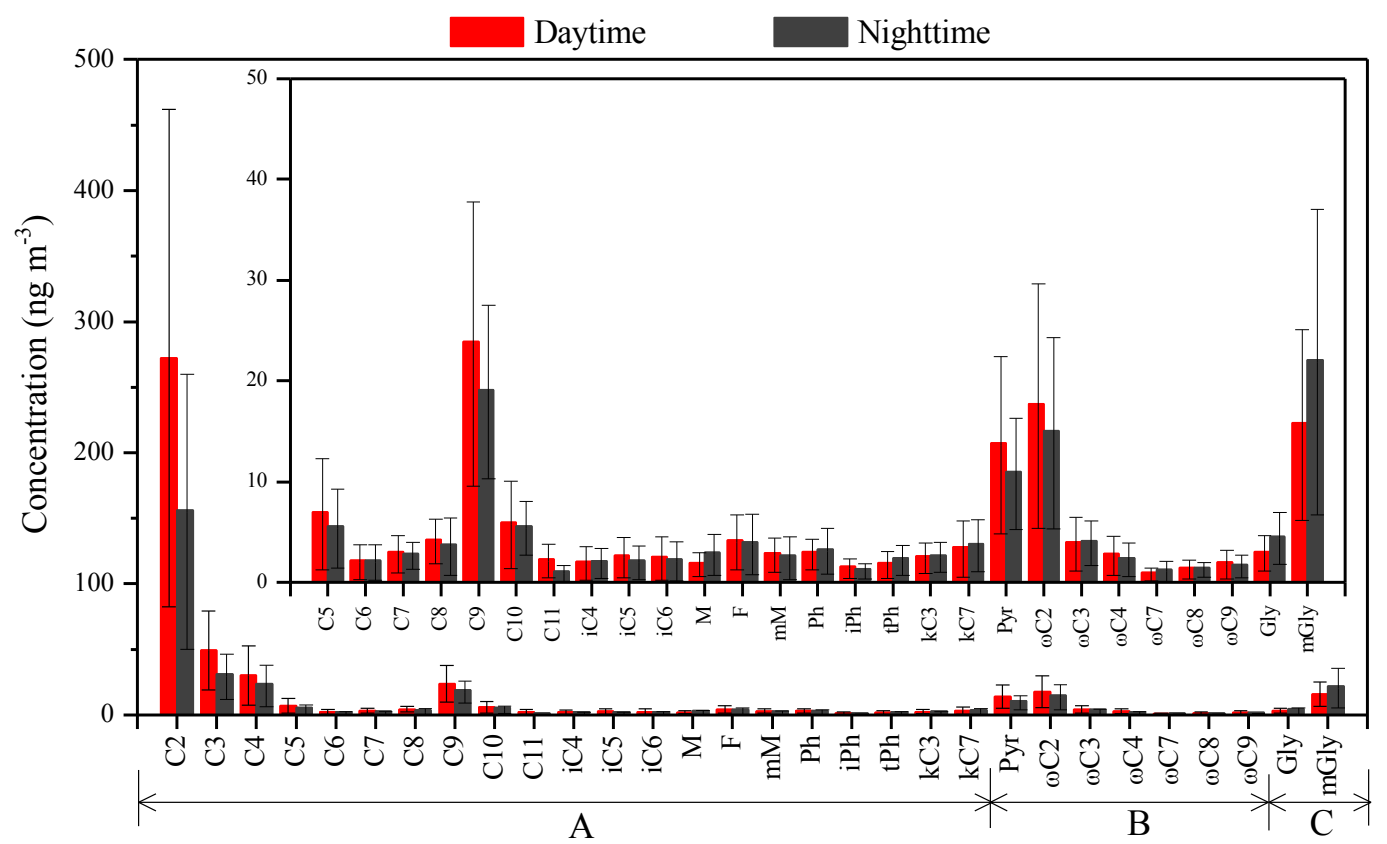

A: Dicarboxylic acids; B: Ketocarboxylic acids; C: $\alpha$-dicarbonyls

Figure 2. Molecular distributions of dicarboxylic acids and related compounds in $\mathrm{PM}_{2.5}$ of Mt. Tai in the North China Plain.

dicarbonyls (glyoxal and methylglyoxal) in $\mathrm{PM}_{2.5}$ samples of Mt. Tai was determined (Table 2). The molecular compositions of these compounds are illustrated in Fig. 2.

Total dicarboxylic acids are $430 \pm 282 \mathrm{ng} \mathrm{m}^{-3}$ $944 \mathrm{ng} \mathrm{m}^{-3}$; Table 2) in the daytime, around 2 times higher than those in the nighttime $\left(282 \pm 161 \mathrm{ng} \mathrm{m}^{-3}\right.$, $73-671 \mathrm{ng} \mathrm{m}^{-3}$ ). The average concentration levels $(354 \pm$ $239 \mathrm{ng} \mathrm{m}^{-3}$ ) are lower than those in Asian lowlands (e.g., 14 Chinese cities (892 $\pm 457 \mathrm{ng} \mathrm{m}^{-3}$ ) (Ho et al., 2007), Chennai in India (502.9 $\pm 117.9 \mathrm{ng} \mathrm{m}^{-3}$ ) (Pavuluri et al., 2010)) and the elevated regions (e.g., Mt. Hua in central China $\left(744 \pm 340 \mathrm{ng} \mathrm{m}^{-3}\right.$ ) (Meng et al., 2014) and the central Himalayas in Nainital, India (430 $\mathrm{ng} \mathrm{m}^{-3}$ ) (Hegde and Kawamura, 2012)), but higher than those in the continental background areas such as Qinghai Lake in the Tibetan Plateau $\left(231 \pm 119 \mathrm{ng} \mathrm{m}^{-3}\right)$ (Meng et al., 2013) and marine regions such as the North Pacific $\left(68 \mathrm{ng} \mathrm{m}^{-3}\right)$ (Hoque et al., 2017) and the western North Pacific (99.2 $\pm 86.4 \mathrm{ng} \mathrm{m}^{-3}$ ) (Boreddy et al., 2017).

Interestingly, we found that the levels of dicarboxylic acids are equivalent to those at Mt. Fuji in Japan in the day and the night (day: $424 \mathrm{ng} \mathrm{m}^{-3}$; night: $266 \mathrm{ng} \mathrm{m}^{-3}$ ) (Mochizuki et al., 2017), which are dominantly derived from the oxidation of biogenic VOCs such as isoprene and $\alpha$-pinene in summer (Mochizuki et al., 2017). Both mountains are located at the similar latitude in East Asia, and the altitudes of the sampling sites at Mt. Tai and Mt. Fuji are almost the same. In addition, both Mt. Tai and Mt. Fuji are dominated by broadleaved forest. Thus, one may expect that the emissions of biogenic VOCs at both sites during the same season are similar. Moreover, the $\mathrm{O}_{3}$ level during the observation period at Mt. Tai is also similar to that at Mt. Fuji, Japan, ranging from a few ppb at night to about $60 \mathrm{ppb}$ (Mochizuki et al., 2017) in the noontime, which means that photochemical activity at both sites during the campaigns is similar. Therefore, concentrations of dicarboxylic acids are comparable at both sites with a similar diurnal pattern.

At the Mt. Tai site, the concentrations of dicarboxylic acids in the daytime were about 2 times higher than in the nighttime, which can be ascribed to the stronger photochemical production of dicarboxylic acids and/or higher emissions of the precursors in the daytime. As shown in Fig. 2, oxalic acid $\left(\mathrm{C}_{2}\right)$ is the dominant species at Mt. Tai, followed by malonic acid $\left(\mathrm{C}_{3}\right)$, succinic acid $\left(\mathrm{C}_{4}\right)$ and azelaic acid $\left(\mathrm{C}_{9}\right)$ during the day and night, respectively. These four species account for $60,12 \%, 7.2 \%$ and $6.9 \%$ of the total dicarboxylic acids in the daytime and $53,11 \%, 8.5 \%$ and $7.6 \%$ of the total in the nighttime, respectively. The molecular compositions at Mt. Tai are similar to those in other remote areas such as Mt. Fuji, Japan, and Mt. Hua and Qinghai Lake, China, in the summer (Meng et al., 2013, 2014; Mochizuki et al., 2017), but different from that in Asian urban regions where phthalic and/or terephthalic acids are more abundant than $\mathrm{C}_{9}$ because of higher emissions of anthropogenic precursors (e.g., aromatics and plasticizers) (Cheng et al., 2015; He et al., 2014; Jung et al., 2010; Wang et al., 2002, 2017).

Ketocarboxylic acids in the atmosphere are the major intermediates of aqueous-phase photochemical oxidation pro- 


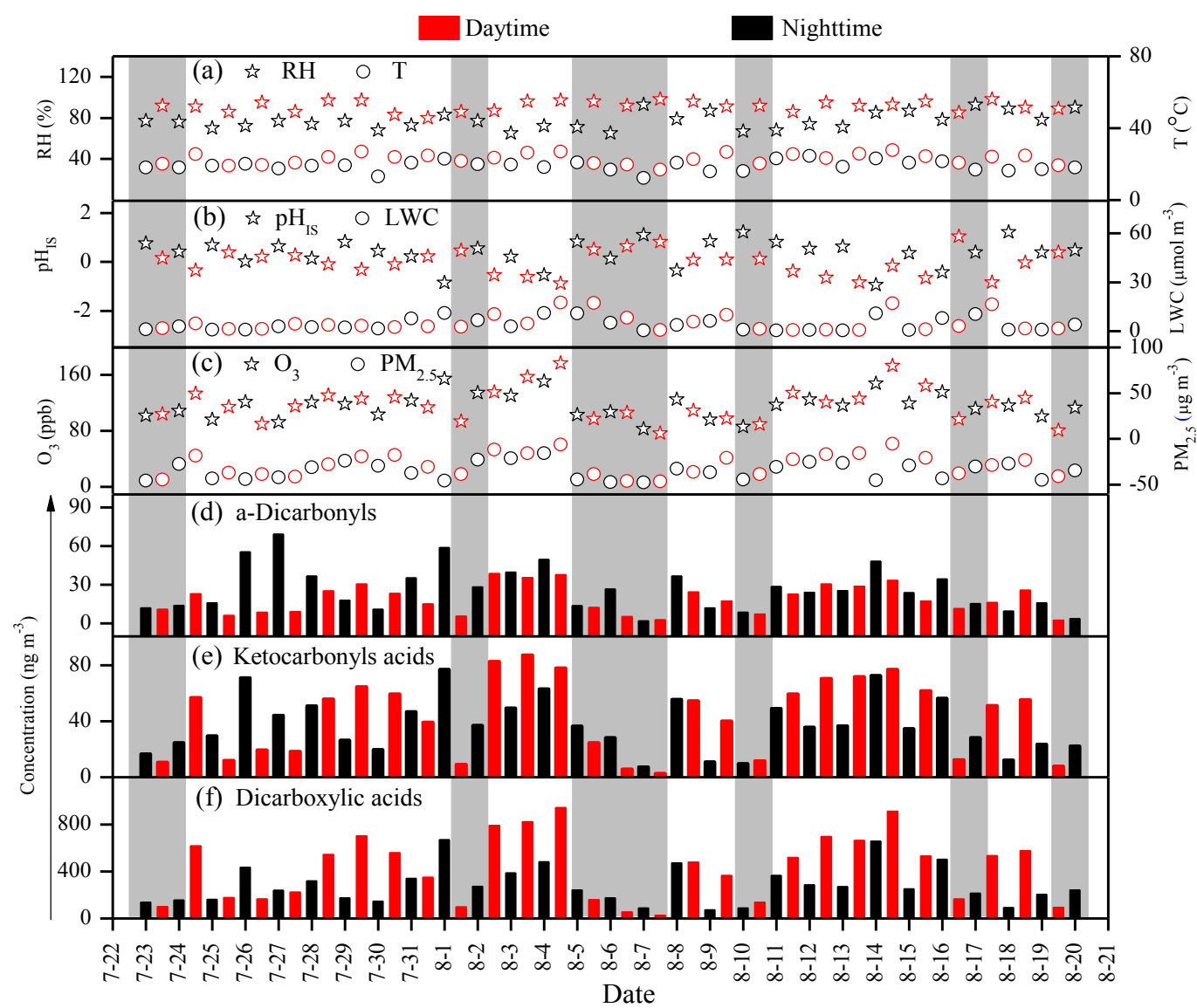

Figure 3. Diurnal variations of relative humidity $(\mathrm{RH})$, temperature $(T)$, in situ acidity of particles $\left(\mathrm{pH}_{\mathrm{IS}}\right)$, liquid water content of particles (LWC), concentrations of $\mathrm{O}_{3}, \mathrm{PM}_{2.5}, \alpha$-dicarbonyls, ketocarboxylic acids and dicarboxylic acids (rainy days are highlighted by the grey shading).

ducing dicarboxylic acids (Kawamura and Ikushima, 1993; Pavuluri and Kawamura, 2016). The concentrations of ketocarboxylic acids are $43 \pm 28 \mathrm{ng} \mathrm{m}^{-3}$ in the daytime and $37 \pm 19 \mathrm{ng} \mathrm{m}^{-3}$ in the nighttime, respectively, with glyoxylic acid $\left(\omega \mathrm{C}_{2}\right)$ being the dominant $\omega$-oxoacid, followed by pyruvic acid (Pyr) and 3-oxobutanoic acid $\left(\omega \mathrm{C}_{3}\right)$ (Table 2 and Fig. 2). Previous studies have proposed that $\omega \mathrm{C}_{2}$ can be initially formed from the photochemical oxidation of glyoxal with $\mathrm{OH}$ radicals and other oxidants in the aqueous phase and then further oxidized into oxalic acid (Wang et al., 2012; Rapf et al., 2017). In contrast to the diurnal variations of dicarboxylic and ketocarboxylic acids, the concentrations of $\alpha$-dicarbonyls exhibit higher concentrations in the nighttime than in the daytime (Fig. 2). Because $\alpha$-dicarbonyls in the aerosol phase are produced by the gas-phase photooxidation of isoprene and other VOCs and the subsequent partitioning into the aerosol aqueous phase (Carlton et al., 2006, 2007), the higher concentrations of $\alpha$-dicarbonyls at night can in part be attributed to the nighttime lower temperatures, which are favorable for the partitioning of gaseous glyoxal and methylglyoxal into the aerosol phase. Since $\alpha$-dicarbonyls are the major precursors of oxalic acid (Fu et al., 2008; Wang et al., 2012; Warneck, 2003), the opposite pattern suggests that the aerosol aqueous-phase oxidation in the daytime is more significant in comparison with that in the nighttime. The concentrations of glyoxal (Gly) are less than methylglyoxal (mGly), largely because of the stronger biogenic sources and the lower oxidation rate of mGly with $\mathrm{OH}$ radicals in the aerosol phase compared to Gly (Cheng et al., 2013; Meng et al., 2013) (see discussions in Sect. 3.3).

Temporal variations in concentrations of total dicarboxylic acids, ketocarboxylic acids and $\alpha$-dicarbonyls are summarized in Fig. 3, along with the meteorological parameters. During the whole sampling periods, the concentrations of total dicarboxylic acids and related SOA fluctuated significantly, with a maximum $\left(1060 \mathrm{ng} \mathrm{m}^{-3}\right)$ on 4 August and a minimum $\left(33 \mathrm{ng} \mathrm{m}^{-3}\right)$ on 7 August. Our results showed that the levels of water-soluble organic compounds decreased by $30 \%-80 \%$ when it was rainy, suggesting that dicarboxylic acids and related SOA can be removed efficiently by wet deposition because these water-soluble compounds are not only easily washed out but also can be efficiently removed 


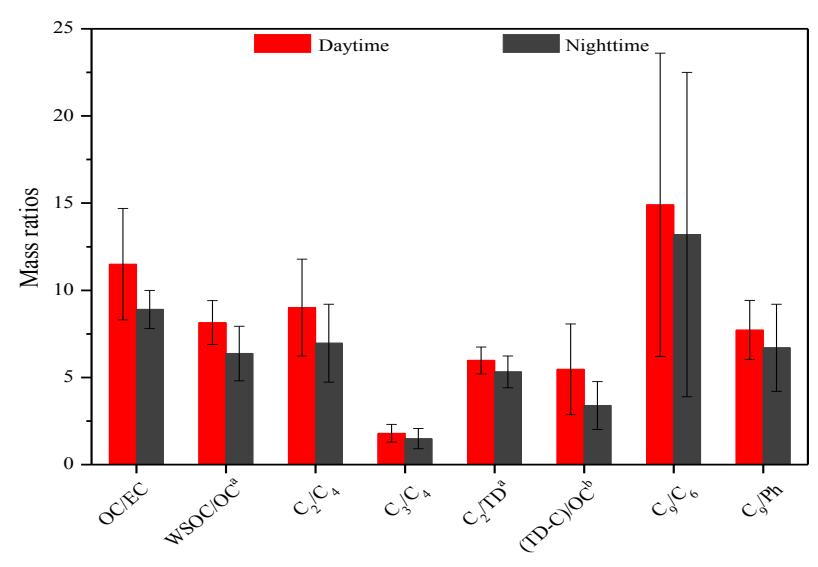

Figure 4. Diurnal variations of mass ratios of $\mathrm{OC} / \mathrm{EC}$, WSOC / OC, $\mathrm{C}_{2} / \mathrm{C}_{4}, \mathrm{C}_{3} / \mathrm{C}_{4}, \mathrm{C}_{2} / \mathrm{TD}$, (TD-C) / OC, $\mathrm{C}_{9} / \mathrm{C}_{6}$ and $\mathrm{C}_{9} / \mathrm{Ph}$. (TD: total dicarboxylic acids; TD-C: the carbon concentration of total dicarboxylic acids. ${ }^{a}$ The mass ratios expanding 10 times. ${ }^{b}$ The mass ratios expanding 100 times).

by serving as cloud condensation nuclei (CCN) during the wet deposition (Leaitch et al., 1996). Moreover, a reduced secondary formation due to weaker solar radiation and a reduced biogenic emission during the rainy days are also responsible for the lowest concentrations of dicarboxylic acid and related SOA.

\subsection{Biogenic versus anthropogenic and local versus long-range transport sources}

Previous studies have proposed that the hydroxylation of $\mathrm{C}_{4}$ can be further oxidized into $\mathrm{C}_{2}$ and $\mathrm{C}_{3}$, and $\mathrm{C}_{3}$ can also be oxidized into $\mathrm{C}_{2}$ through intermediate compounds such as hydroxymalonic acid or ketomalonic acid (Hoque et al., 2017; Kawamura and Usukura, 1993; Kunwar et al., 2017). Therefore, both ratios of $\mathrm{C}_{2} / \mathrm{C}_{4}$ and $\mathrm{C}_{3} / \mathrm{C}_{4}$ can be regarded as indicators of photochemical aging of organic aerosols. The $\mathrm{C}_{2} / \mathrm{C}_{4}$ and $\mathrm{C}_{3} / \mathrm{C}_{4}$ ratios in the mountainous atmosphere are $8.0 \pm 2.7$ and $1.6 \pm 0.6$, respectively, higher than those in aerosols freshly emitted from sources such as vehicle exhausts $\left(\mathrm{C}_{2} / \mathrm{C}_{4}\right.$ : 4.1; $\mathrm{C}_{3} / \mathrm{C}_{4}$ : 0.35) (Kawamura and Kaplan, $1987)$ and biomass burning plumes $\left(C_{2} / C_{4}: 5.0 ; C_{3} / C_{4}\right.$ : 0.7) (Kundu et al., 2010), but lower than photochemically aged aerosols in remote regions such as a continental background site in the Tibetan Plateau $\left(\mathrm{C}_{2} / \mathrm{C}_{4}\right.$ : $11 \pm 7.2 ; \mathrm{C}_{3} / \mathrm{C}_{4}$ : $2.2 \pm 1.3$ ) (Meng et al., 2013) and the North and South Pacific $\left(\mathrm{C}_{2} / \mathrm{C}_{4}\right.$ : 8.7; $\mathrm{C}_{3} / \mathrm{C}_{4}$ : 3.0) (Hoque et al., 2017). Compared with those in the nighttime, the higher ratios of $\mathrm{C}_{2} / \mathrm{C}_{4}$ and $\mathrm{C}_{3} / \mathrm{C}_{4}$ (Fig. 4) in the daytime again indicated that the photochemical modification of aerosols is stronger. Decomposition of $\mathrm{C}_{4}$ and/or $\mathrm{C}_{3}$ into $\mathrm{C}_{2}$ is one of the major formation pathways of oxalic acid, which is favored by temperature (Kawamura and Ikushima, 1993). A few studies have reported that when local sources are dominant over long- range transport, both ratios of $\mathrm{C}_{2} / \mathrm{C}_{4}$ and $\mathrm{C}_{3} / \mathrm{C}_{4}$ correlate strongly with the ambient temperatures (Kawamura and Ikushima, 1993; Meng et al., 2013; Pavuluri et al., 2010). Temperature measured at the sampling site is a meteorological parameter, which only reflects the local meteorological conditions rather than the upwind conditions. Therefore, a significant correlation between $\mathrm{C}_{2} / \mathrm{C}_{4}$ and temperature can only be observed when SOA are largely derived from local precursor oxidation rather than from long-range transport. In the current work, the ratios of $\mathrm{C}_{2} / \mathrm{C}_{4}\left(R^{2}>0.5\right)$ (Fig. 5a) and $\mathrm{C}_{3} / \mathrm{C}_{4}\left(R^{2} \geq 0.5\right)$ (Fig. 5b) correlated well with the ambient temperatures in both the daytime and the nighttime, clearly suggesting that dicarboxylic acids and related SOA at Mt. Tai during the campaign are mostly derived from the local oxidation of BVOCs rather than long-range transport. Aggarwal et al. (2008) found that diacid-C / OC and $\mathrm{C}_{2}$ / total diacids should increase in the daytime when local emission and photooxidation are more significant than longrange transport. At the summit of Mt. Tai, the daytime ratios of diacid-C / OC and $\mathrm{C}_{2}$ / total diacids are $5.5 \% \pm 2.6 \%$ and $60 \% \pm 7.7 \%$, which are about 1.2 and 1.3 times higher than those in the nighttime, respectively (Fig. 4), further indicating the stronger photochemical oxidation in the daytime and the dominance of local sources for SOA production in the atmosphere of Mt. Tai.

Both ratios of $\mathrm{C}_{9} / \mathrm{C}_{6}$ and $\mathrm{C}_{9} / \mathrm{Ph}$ can be used as indicators to qualitatively evaluate the source strength of anthropogenic versus biogenic precursors for producing dicarboxylic acids and related SOA (Jung et al., 2010) because $\mathrm{C}_{6}$ and $\mathrm{Ph}$ are largely produced by the oxidation of anthropogenic cyclohexene (Hatakeyama et al., 1987) and aromatic hydrocarbons such as naphthalene (Kawamura and Ikushima, 1993), respectively. In contrast, $C_{9}$ is mainly produced by the oxidation of biogenic unsaturated oleic acid, which contains a double bond at the C-9 position (Wang et al., 2010). Therefore, both ratios of $\mathrm{C}_{9} / \mathrm{C}_{6}$ and $\mathrm{C}_{9} / \mathrm{Ph}$ are indicative of the source strengths of biogenic versus anthropogenic emissions. As shown in Fig. 4, both ratios of $\mathrm{C}_{9} / \mathrm{C}_{6}$ and $\mathrm{C}_{9} / \mathrm{Ph}$ are similar in the daytime to those in the nighttime. However, the average values of $\mathrm{C}_{9} / \mathrm{C}_{6}(14 \pm 9.0)$ and $\mathrm{C}_{9} / \mathrm{Ph}(7.2 \pm 2.2)$ at the mountaintop of Mt. Tai are higher than those in urban regions such as $\mathrm{Xi}$ ' an, China $\left(\mathrm{C}_{9} / \mathrm{C}_{6}\right.$ : 3.1; $\mathrm{C}_{9}$ / Ph: 5.6) (Cheng et al., 2013), and also higher than those in other mountainous areas during summer such as the central Himalayas, India $\left(\mathrm{C}_{9} / \mathrm{C}_{6}: 2.1 ; \mathrm{C}_{9} / \mathrm{Ph}: 0.2\right)$ (Hegde and Kawamura, 2012), and Mt. Fuji, Japan ( $\left.\mathrm{C}_{9} / \mathrm{C}_{6}: 3.1\right)$ (Mochizuki et al., 2017), indicating the important contribution of biogenic sources to SOA in the Mt. Tai region. Model simulation (Fu et al., 2008) and field observations (Meng et al., 2014) have suggested that the concentration ratio of particulate Gly/mGly is about 1:5 when biogenic sources are predominant and is about $1: 1$ when anthropogenic sources are predominant such as in urban areas. As shown in Table 3, the ratios of Gly/mGly in the Mt. Tai atmosphere are $1: 5.1$ in the daytime and $1: 4.8$ in the nighttime, further suggesting 
Table 3. Concentrations of $\alpha$-dicarbonyls in $\mathrm{PM}_{2.5}$ from Mt. Tai and Mt. Hua in China and the global budgets of atmospheric Gly and mGly.

\begin{tabular}{llrr|c}
\hline \multirow{2}{*}{ Site } & Sources/season & \multicolumn{2}{c|}{ Abundance } & Mass ratio \\
\cline { 2 - 5 } & & Gly & mGly & Gly/mGly \\
\hline Global budget $\left(\mathrm{Tg} \mathrm{a}^{-1}\right)$ & Biogenic & $22.8^{\mathrm{a}}$ & $113.5^{\mathrm{a}}$ & $1: 5$ \\
& Anthropogenic & $22.2^{\mathrm{a}}$ & $26.5^{\mathrm{a}}$ & $1: 1$ \\
\hline \multirow{2}{*}{ Mt. Hua $\left(\mathrm{ng} \mathrm{m}^{-3}\right)$} & Biogenic, summer & $2.3^{\mathrm{b}}$ & $10^{\mathrm{b}}$ & $1: 4.4$ \\
& Anthropogenic, winter & $8.8^{\mathrm{b}}$ & $1.3^{\mathrm{b}}$ & $1: 1.5$ \\
\hline \multirow{2}{*}{ Mt. Tai $\left(\mathrm{ng} \mathrm{m}^{-3}\right.$; this study) } & Summer, daytime & 3.1 & 15.8 & $1: 5.1$ \\
& Summer, nighttime & 4.6 & 22.1 & $1: 4.8$ \\
\hline
\end{tabular}

${ }^{a}$ Data are calculated from Fu et al. (2008). ${ }^{b}$ Data are cited from Meng et al. (2014).
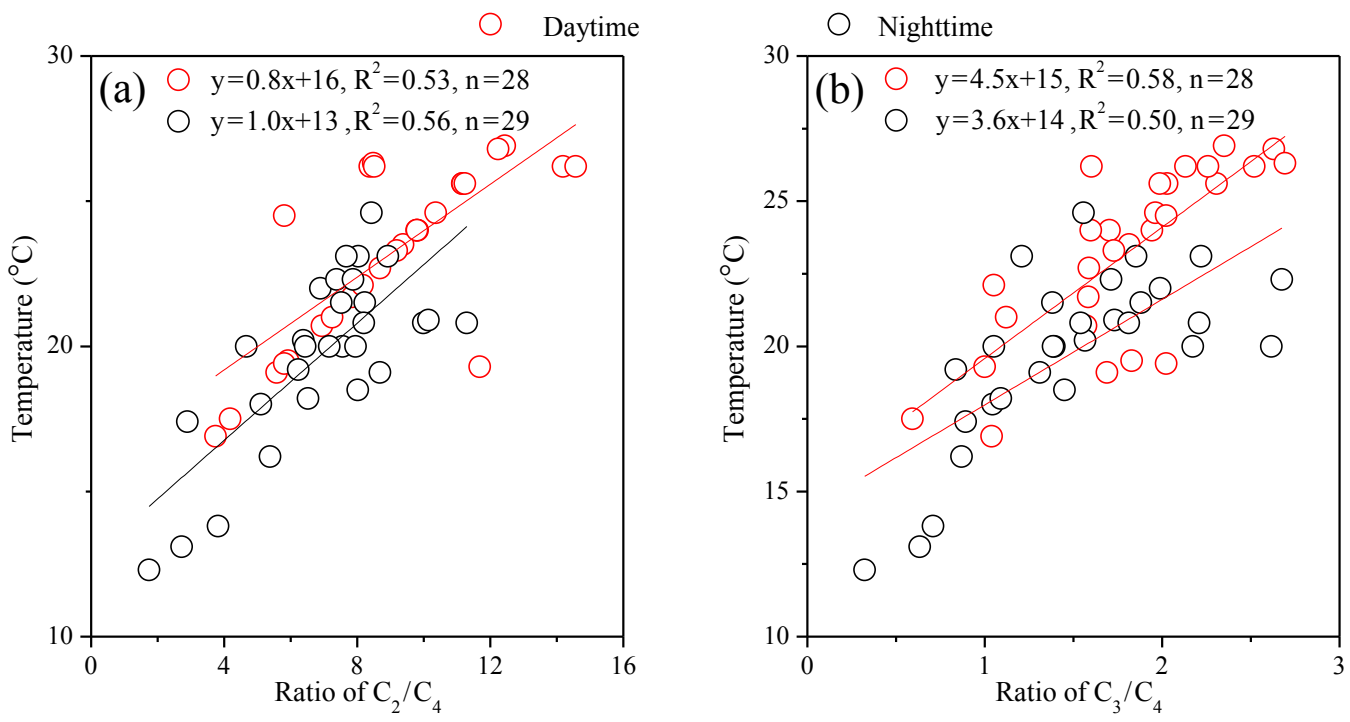

Figure 5. Linear fit regression for temperature $(T)$ with mass ratios of (a) $C_{2} / C_{4}$ and (b) $C_{3} / C_{4}$ (see the abbreviations in Table 1).

that Gly and mGly in the Mt. Tai samples are mostly derived from biogenic sources. This result is also in agreement with the high abundance of $\mathrm{C}_{9}$ relative to the total dicarboxylic acids $(7.2 \%)$, which is about 2 times higher than that $(3.5 \%)$ in 14 Chinese megacities (Ho et al., 2007). Moreover, a trace amount of elemental carbon (EC) was found for most of the samples (Table 1), suggesting that the impact of pollutants derived from anthropogenic sources on the mountaintop atmosphere during the campaign is negligible. Consequently, it can be concluded that the summertime SOA of Mt. Tai are mainly derived from the local photochemical oxidation of biogenic precursors rather than the long-range transport of anthropogenic precursors during the sampling period.

\subsection{Production of dicarboxylic acids and related SOA from biogenic sources}

A 3-D modeling study has proposed that $79 \%$ of oxalic acid is originated from the photochemical oxidation of isoprene and other biogenic hydrocarbons in cloud (Myriokefalitakis et al., 2011). Laboratory experiments and model simulations have demonstrated that the photooxidation of isoprene (Carlton et al., 2006, 2007; Huang et al., 2011) and monoterpenes (Fick et al., 2003; Lee et al., 2006) can produce Gly and mGly via reactions with $\mathrm{OH}$ radicals and/or $\mathrm{O}_{3}$ in the aerosol aqueous phase or the gas phase and subsequently partition into cloud droplets, where both carbonyls are oxidized further by $\mathrm{OH}$ radicals to form oxalic acid (Lim et al., 2005; Tan et al., 2010).

In order to further ascertain the contribution of BVOCs to dicarboxylic acids and related SOA during the high biological activity period at Mt. Tai, SOA tracers derived from isoprene, $\alpha$ - $/ \beta$-pinene and $\beta$-caryophyllene in the $\mathrm{PM}_{2.5}$ samples collected at the Mt. Tai site were determined. Their total concentrations (the sum of isoprene $+\alpha-/ \beta$-pinene $+\beta$ caryophyllene-derived SOA tracers) are 1.3 times higher in the daytime $\left(106 \pm 56 \mathrm{ng} \mathrm{m}^{-3}\right)$ than those in the nighttime $\left(79 \pm 38 \mathrm{ng} \mathrm{m}^{-3}\right.$ ) (unpublished data), which is consistent with 
Table 4. Correlation coefficients $(R)$ matrix among major low molecular weight dicarboxylic acids and related SOA, BSOA tracers, temperature $(T)$ and $\mathrm{O}_{3}$ concentrations at Mt. Tai during the summer campaign.

\begin{tabular}{|c|c|c|c|c|c|c|c|c|c|c|}
\hline & BSOA tracer & $\mathrm{C}_{2}$ & $\mathrm{C}_{3}$ & $\mathrm{C}_{4}$ & $\omega \mathrm{C}_{2}$ & Pyr & Gly & mGly & $\mathrm{O}_{3}$ & $T$ \\
\hline \multicolumn{11}{|l|}{ Daytime } \\
\hline \multirow{3}{*}{ Isoprene-derived SOA } & 2-Methylglyceric acid & $0.98^{\mathrm{a}}$ & $0.96^{\mathrm{a}}$ & $0.86^{\mathrm{a}}$ & $0.95^{\mathrm{a}}$ & $0.73^{\mathrm{a}}$ & $0.96^{\mathrm{a}}$ & $0.94^{\mathrm{a}}$ & $0.92^{\mathrm{a}}$ & $0.85^{\mathrm{a}}$ \\
\hline & 2-Methylthreitol & $0.83^{\mathrm{a}}$ & $0.80^{\mathrm{a}}$ & $0.64^{\mathrm{a}}$ & $0.74^{\mathrm{a}}$ & $0.77^{\mathrm{a}}$ & $0.77^{\mathrm{a}}$ & $0.82^{\mathrm{a}}$ & $0.85^{\mathrm{a}}$ & $0.72^{\mathrm{a}}$ \\
\hline & 2-Methylerythritol & $0.84^{\mathrm{a}}$ & $0.87^{\mathrm{a}}$ & $0.70^{\mathrm{a}}$ & $0.78^{\mathrm{a}}$ & $0.83^{\mathrm{a}}$ & $0.83^{\mathrm{a}}$ & $0.84^{\mathrm{a}}$ & $0.80^{\mathrm{a}}$ & $0.71^{\mathrm{a}}$ \\
\hline \multirow{3}{*}{$\alpha / \beta$-Pinene-derived SOA } & cis-Pinonic acid & $0.83^{\mathrm{a}}$ & $0.75^{\mathrm{a}}$ & $0.73^{\mathrm{a}}$ & $0.75^{\mathrm{a}}$ & $0.74^{\mathrm{a}}$ & $0.71^{\mathrm{a}}$ & $0.77^{\mathrm{a}}$ & $0.80^{\mathrm{a}}$ & $0.72^{\mathrm{a}}$ \\
\hline & 3-Hydroxyglutaric acid & $0.81^{\mathrm{a}}$ & $0.76^{\mathrm{a}}$ & $0.69^{\mathrm{a}}$ & $0.74^{\mathrm{a}}$ & $0.78^{\mathrm{a}}$ & $0.74^{\mathrm{a}}$ & $0.73^{\mathrm{a}}$ & $0.73^{\mathrm{a}}$ & $0.75^{\mathrm{a}}$ \\
\hline & $\mathrm{MBTCA}^{\mathrm{c}}$ & $0.84^{\mathrm{a}}$ & $0.77^{\mathrm{a}}$ & $0.83^{\mathrm{a}}$ & $0.82^{\mathrm{a}}$ & $0.75^{\mathrm{a}}$ & $0.74^{\mathrm{a}}$ & $0.77^{\mathrm{a}}$ & $0.82^{\mathrm{a}}$ & $0.67^{\mathrm{a}}$ \\
\hline$\beta$-Caryophyllene-derived SOA & $\beta$-Caryophyllinic acid & $0.75^{\mathrm{a}}$ & $0.70^{\mathrm{a}}$ & $0.79^{a}$ & $0.70^{\mathrm{a}}$ & $0.70^{\mathrm{a}}$ & $0.71^{\mathrm{a}}$ & $0.72^{\mathrm{a}}$ & $0.65^{\mathrm{a}}$ & $0.57^{\mathrm{a}}$ \\
\hline \multicolumn{11}{|l|}{ Nighttime } \\
\hline \multirow{4}{*}{ Isoprene-derived SOA } & 2-Methylglyceric acid & $0.87^{\mathrm{a}}$ & $0.72^{\mathrm{a}}$ & $0.74^{\mathrm{a}}$ & $0.70^{\mathrm{a}}$ & $0.64^{\mathrm{a}}$ & $0.44^{\mathrm{b}}$ & $0.51^{\mathrm{a}}$ & 0.09 & $0.59^{\mathrm{a}}$ \\
\hline & 2-Methylthreitol & $0.81^{\mathrm{a}}$ & $0.71^{\mathrm{a}}$ & $0.58^{\mathrm{a}}$ & $0.71^{\mathrm{a}}$ & $0.66^{\mathrm{a}}$ & $0.60^{\mathrm{a}}$ & $0.47^{\mathrm{b}}$ & $0.05^{\mathrm{a}}$ & $0.65^{\mathrm{a}}$ \\
\hline & 2-Methylerythritol & $0.83^{\mathrm{a}}$ & $0.72^{\mathrm{a}}$ & $0.62^{\mathrm{a}}$ & $0.79^{\mathrm{a}}$ & $0.73^{\mathrm{a}}$ & $0.67^{\mathrm{a}}$ & $0.61^{\mathrm{a}}$ & 0.23 & $0.74^{\mathrm{a}}$ \\
\hline & cis-Pinonic acid & $0.83^{\mathrm{a}}$ & $0.65^{\mathrm{a}}$ & $0.57^{\mathrm{a}}$ & $0.75^{\mathrm{a}}$ & $0.61^{\mathrm{a}}$ & $0.56^{\mathrm{a}}$ & $0.54^{\mathrm{a}}$ & 0.22 & $0.63^{\mathrm{a}}$ \\
\hline \multirow[t]{2}{*}{$\alpha / \beta$-Pinene-derived SOA } & 3-Hydroxyglutaric acid & $0.79^{\mathrm{a}}$ & $0.62^{\mathrm{a}}$ & $0.69^{\mathrm{a}}$ & $0.71^{\mathrm{a}}$ & $0.60^{\mathrm{a}}$ & $0.58^{\mathrm{a}}$ & $0.50^{\mathrm{a}}$ & $0.43^{\mathrm{b}}$ & $0.62^{\mathrm{a}}$ \\
\hline & MBTCA $^{\mathrm{c}}$ & $0.82^{\mathrm{a}}$ & $0.80^{\mathrm{a}}$ & $0.78^{\mathrm{a}}$ & $0.73^{\mathrm{a}}$ & $0.75^{\mathrm{a}}$ & $0.61^{\mathrm{a}}$ & $0.55^{\mathrm{a}}$ & 0.30 & $0.60^{\mathrm{a}}$ \\
\hline$\beta$-Caryophyllene-derived SOA & $\beta$-Caryophyllinic acid & $0.68^{\mathrm{a}}$ & $0.74^{\mathrm{a}}$ & $0.61^{\mathrm{a}}$ & $0.73^{\mathrm{a}}$ & $0.71^{\mathrm{a}}$ & $0.73^{\mathrm{a}}$ & $0.58^{\mathrm{a}}$ & $0.32^{\mathrm{a}}$ & $0.53^{\mathrm{a}}$ \\
\hline
\end{tabular}

the diurnal variation patterns of dicarboxylic acids, ketocarboxylic acids and WSOC (Tables 1 and 2). Previous studies reported that 2-methylglyceric acid, which is an isoprene oxidation product, and 3-hydroxyglutaric acid, which is $\alpha$ $/ \beta$-pinene oxidation product, can serve as organic precursors for the production of dicarboxylic acids and ketocarboxylic acids (Fu et al., 2013). As shown in Table 4, major dicarboxylic acids and related SOA (e.g., $\mathrm{C}_{2}, \omega \mathrm{C}_{2}$, Gly and mGly) correlated positively with the isoprene, $\alpha / \beta$-pinene and $\beta$-caryophyllene oxidation products during the day and night $(R>0.55, P<0.01)$ (Table 4$)$, respectively, indicating that BVOCs' oxidation products can serve as precursors for the production of oxalic acid via $\alpha$-dicarbonyls' oxidation (Myriokefalitakis et al., 2011). These strong correlations further highlight the important contribution of BSOA to dicarboxylic acids and related SOA at Mt. Tai in the summer season.

\subsection{Effects of temperature, relative humidity and $\mathrm{O}_{3}$ concentrations on the formation of oxalic acid and related SOA}

Because oxidants such as $\mathrm{OH}$ radicals were not measured at Mt. Tai, $\mathrm{O}_{3}$ is considered here as an indicator of the total oxidant concentrations in this study. A significant linear correlation of oxalic acid with $\mathrm{O}_{3}$ concentrations was observed for the daytime samples $\left(R^{2}=0.91\right)$, but no correlation $\left(R^{2}=0.05\right)$ was found for the nighttime samples (Fig. 6a). Such a phenomenon was also observed at Mt. Fuji, Japan (Mochizuki et al., 2017), and Beijing, China (He et al., 2014). Additionally, $\mathrm{C}_{2}$ / Gly, $\mathrm{C}_{2} / \mathrm{mGly}$ and $\mathrm{C}_{2}$ / total diacids ratios correlate positively with $\mathrm{O}_{3}$ concentrations in the daytime, but such correlations were not found in the nighttime (Fig. 8a-c). Mochizuki et al. (2017) have reported a robust correlation between concentration ratios of oxalic acid to isoprene plus $\alpha$-pinene (oxalic acid / (isoprene $+\alpha$ pinene)) and $\mathrm{O}_{3}$ concentrations in a large forest region of Mt. Fuji, Japan, in the daytime. In the current work, BSOA tracers correlate strongly with $\mathrm{O}_{3}$ concentrations in the daytime $(R>0.6, P<0.01)$, but no correlation was found at night (Table 4). These results suggest that the daytime oxalic acid and related SOA in the mountaintop of Mt. Tai are largely derived from $\mathrm{O}_{3}$ and $\mathrm{OH}$ radical oxidation of BVOCs such as isoprene and $\alpha$-pinene, while the nighttime oxalic acid and related SOA might be mostly produced by $\mathrm{NO}_{3}$ radicals and other oxidizing agents such as $\mathrm{H}_{2} \mathrm{O}_{2}$ (Claeys et al., 2004; Herrmann et al., 1999). In addition, the titration of $\mathrm{O}_{3}$ by the residual NO in the nighttime atmosphere could also be responsible for the lack of correlation between BSOA tracers and $\mathrm{O}_{3}$ (Edwards et al., 2017).

As shown in Table 4, nearly all of the detected BSOA tracers including 2-methylglyceric acid, 3-hydroxyglutaric acid and $\beta$-caryophyllinic acid exhibit a strong correlation with the ambient temperature, largely due to the increased production of BSOA from enhanced emissions of BVOCs under higher temperature conditions. The BSOA tracer concentrations are higher in the daytime than in the nighttime. As seen in Table $1, \mathrm{O}_{3}$ concentration during the sampling period is $50 \%$ higher in the daytime than in the nighttime, clearly in- 

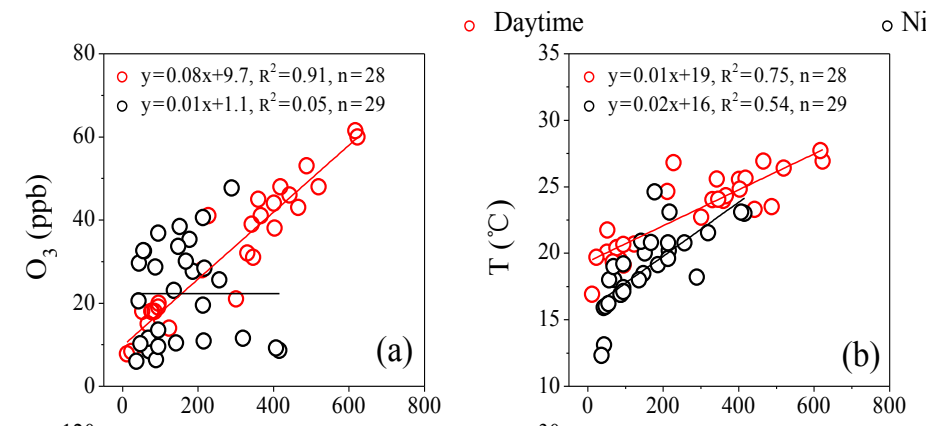

- Nighttime
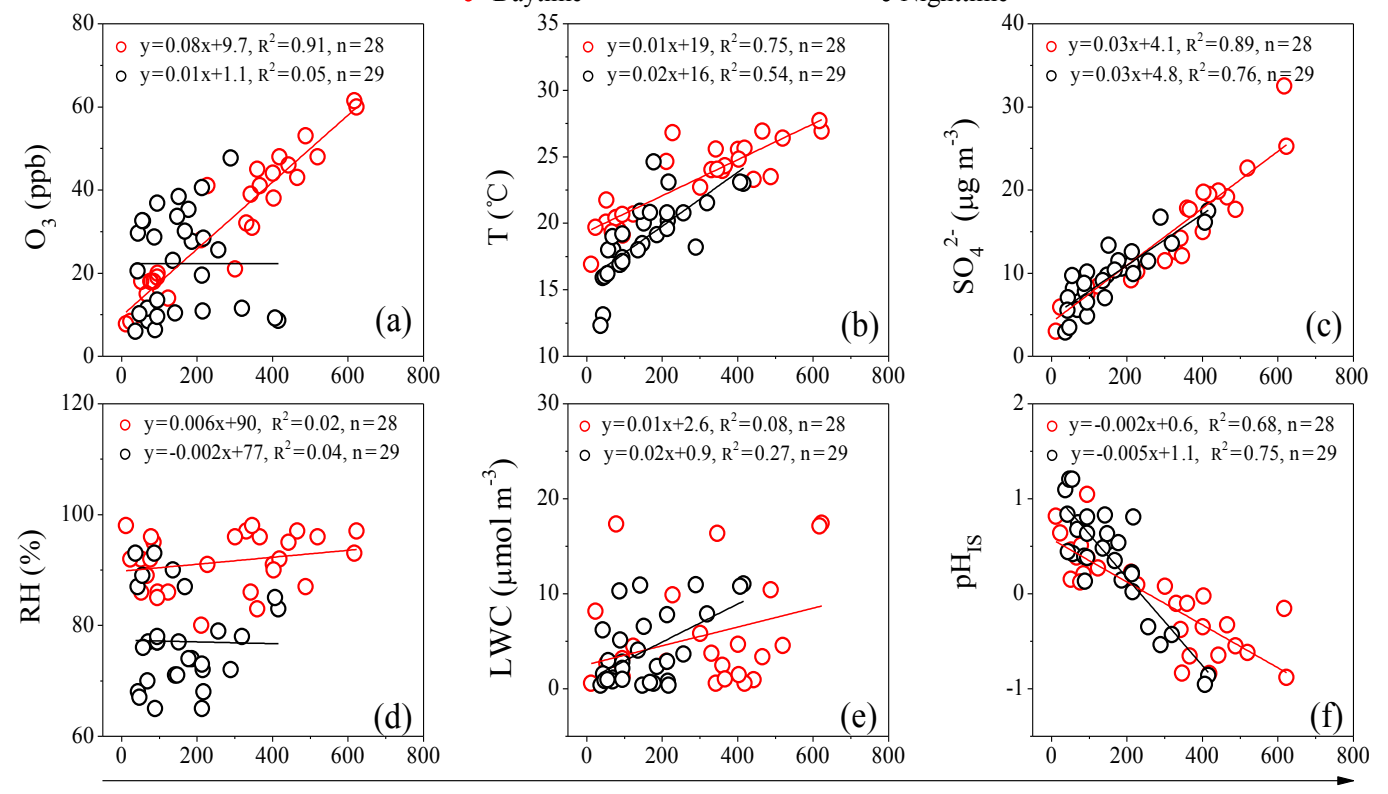

Oxalic acid $\left(\mathrm{ng} \mathrm{m}^{-3}\right)$

Figure 6. Linear fit regressions of oxalic acid $\left(\mathrm{C}_{2}\right)$ with $(\mathbf{a}) \mathrm{O}_{3}$, (b) temperature $(T),(\mathbf{c}) \mathrm{SO}_{4}^{2-}$, (d) relative humidity $(\mathrm{RH})$, (e) aerosol liquid water content (LWC) and (f) in situ acidity of particles $\left(\mathrm{pH}_{\mathrm{IS}}\right)$.

dicating that oxidation potential in the daytime at the Mt. Tai site is stronger. Moreover, isoprene is only emitted by trees during daytime. Thus, we think the higher loadings of BSOA tracers in the daytime are caused not only by stronger photochemical oxidation but also by enhanced emissions of BVOCs. In addition, oxalic acid and $\mathrm{C}_{2}$ / total diacids ratios correlated strongly with temperatures (Figs. $6 \mathrm{~b}$ and $8 \mathrm{f}$ ) because higher temperature conditions can promote photochemical formation of oxalic acid. Such a temperature dependence is also observed in other regions such as Mt. Hua (Meng et al., 2014) and Beijing (Wang et al., 2017) in China.

Online measurements, field observations and chamber studies (Cheng et al., 2017; Gao et al., 2004; McNeill, 2015; Meng et al., 2014; Wang et al., 2012, 2017) have suggested that oxalic acid is primarily derived from the acid-catalyzed heterogeneous oxidation of glyoxal and related precursors in the aqueous phase. Here we investigate the impact of LWC and $\mathrm{pH}_{\mathrm{IS}}$ on the formation of oxalic acid in Mt. Tai aerosols. Because the sampling site is far from agricultural sources, most of the sulfate is assumed to be acidic. As shown in Fig. 6c, a strong linear correlation between $\mathrm{C}_{2}$ and $\mathrm{SO}_{4}^{2-}$ was found for the daytime $\left(R^{2}=0.89\right)$ and nighttime $\left(R^{2}=0.76\right)$ samples, respectively, which is consistent with the measurements observed in other mountainous regions (Meng et al., 2014) and Chinese cities (Wang et al., 2012, 2017; Yu et al., 2005), indicating that oxalic acid and sulfate are formed via a similar formation pathway such as in-cloud or aqueous-phase (Warneck, 2003). In this study, oxalic acid does not exhibit correlations with relative humidity $(\mathrm{RH})$ and
LWC (Fig. 6d and e), but presents a significant negative correlation with $\mathrm{pH}_{\mathrm{IS}}\left(R^{2}>0.60\right)$ (Fig. 6f), largely due to the fact that acidic conditions can promote the formation of oxalic acid and their precursors. Therefore, a robust negative correlation was obtained for $\mathrm{pH}_{\mathrm{IS}}$ and the precursors of oxalic acid such as Gly, mGly and $\omega \mathrm{C}_{2}\left(R^{2}>0.50\right)$. A few studies have pointed out that aerosol acidity is favorable for the formation of biogenic SOA (BSOA) derived from isoprene oxidation such as 2-methylglyceric acid, which can be oxidized into Gly and mGly and then converted to oxalic acid (Meng et al., 2014; Surratt et al., 2007, 2010). Our previous studies have revealed that enhanced RH can reduce particle acidity $\left(\mathrm{pH}_{\mathrm{IS}}\right.$ ) and is thus unfavorable for oxalic acid formation by acid-catalyzed reactions occurring in the aerosol aqueous phase (Meng et al., 2014). Both RH and aerosol composition are key factors controlling the aerosol LWC (Bikkina et al., 2017). Deshmukh et al. (2017) and Bikkina et al. (2017) also found that RH and LWC correlated well with oxalic acid, indicating that humid conditions are favorable for the aqueous-phase formation of $\mathrm{C}_{2}$. Nevertheless, Zhang et al. (2011) pointed out that low RH conditions can promote SOA yields via the oxidation of isoprene. Higher $\mathrm{RH}$ and LWC can promote the partitioning of water-soluble semi-volatile organic precursors of oxalic acid (e.g., Gly and mGly) into the aerosol aqueous phase but can also suppress the acid-catalyzed formation of oxalic acid because of the lower aerosol acidity due to dilution. Therefore, $\mathrm{C}_{2}$ does not present any correlation with RH or LWC at Mt. Tai. 
Table 5. Stable carbon isotopic compositions $\left(\delta^{13} \mathrm{C}, \%\right.$ o of major dicarboxylic acids and related SOA in PM 2.5 of Mt. Tai in the North China Plain.

\begin{tabular}{|c|c|c|c|}
\hline Compounds & Daytime $(n=28)$ & Nighttime $(n=29)$ & Total $(n=57)$ \\
\hline \multicolumn{4}{|l|}{ Dicarboxylic acids } \\
\hline Oxalic, $\mathrm{C}_{2}$ & $-15.8 \pm 1.9(-19.4$ to -13.0$)$ & $-17.2 \pm 1.7(-20.1$ to -12.1$)$ & $-16.5 \pm 1.9(-20.1$ to -12.1$)$ \\
\hline Malonic, $\mathrm{C}_{3}$ & $-19.1 \pm 2.3(-23.8$ to -15.9$)$ & $-18.5 \pm 1.8(-21.1$ to -15.3$)$ & $-18.8 \pm 2.0(-23.8$ to -15.3$)$ \\
\hline Succinic, $\mathrm{C}_{4}$ & $-22.0 \pm 2.3(-25.6$ to -18.5$)$ & $-21.4 \pm 2.2(-24.6$ to -18.4$)$ & $-21.7 \pm 2.2(-25.6$ to -18.4$)$ \\
\hline Adipic, $\mathrm{C}_{6}$ & $-23.7 \pm 2.5(-27.3$ to -19.9$)$ & $-24.8 \pm 2.4(-27.9$ to -21.4$)$ & $-24.2 \pm 2.5(-27.9$ to -19.9$)$ \\
\hline Azelaic, $\mathrm{C}_{9}$ & $-24.7 \pm 2.6(-28.7$ to -21.0$)$ & $-25.7 \pm 2.7(-30.3$ to -21.9$)$ & $-25.2 \pm 2.7(-30.3$ to -21.0$)$ \\
\hline Phthalic, $\mathrm{Ph}$ & $-24.3 \pm 2.5(-28.1$ to -20.6$)$ & $-25.2 \pm 2.6(-29.2$ to -20.9$)$ & $-24.8 \pm 2.5(-29.2$ to -20.6$)$ \\
\hline \multicolumn{4}{|l|}{ Ketocarboxylic acids } \\
\hline Pyruvic, Pyr & $-19.4 \pm 2.1(-23.1$ to -16.5$)$ & $-21.2 \pm 2.2(-24.5$ to -17.8$)$ & $-20.3 \pm 2.3(-24.5$ to -16.5$)$ \\
\hline Glyoxylic, $\omega \mathrm{C}_{2}$ & $-18.6 .8 \pm 1.9(-21.5$ to -15.6$)$ & $-20.2 \pm 2.1(-23.1$ to -16.9$)$ & $-19.4 \pm 2.2(-23.1$ to -15.6$)$ \\
\hline 3-Oxopropanoic, $\omega \mathrm{C}_{3}$ & $-20.2 \pm 2.1(-23.5$ to -17.0$)$ & $-24.0 \pm 2.5(-27.7$ to -20.8$)$ & $-22.2 \pm 3.0(-27.7$ to -17.0$)$ \\
\hline \multicolumn{4}{|l|}{$\alpha$-Dicarbonyls } \\
\hline Glyoxal, Gly & $-16.7 \pm 1.7(-19.4$ to -14.0$)$ & $-18.1 \pm 1.8(-21.3$ to -15.2$)$ & $-17.4 \pm 1.9(-21.3$ to -14.0$)$ \\
\hline Methyglyoxal, mGly & $-17.9 \pm 1.8(-21.0$ to -15.0$)$ & $-19.6 \pm 2.0(-22.5$ to -16.5$)$ & $-18.8 \pm 2.1(-22.5$ to -15.0$)$ \\
\hline
\end{tabular}

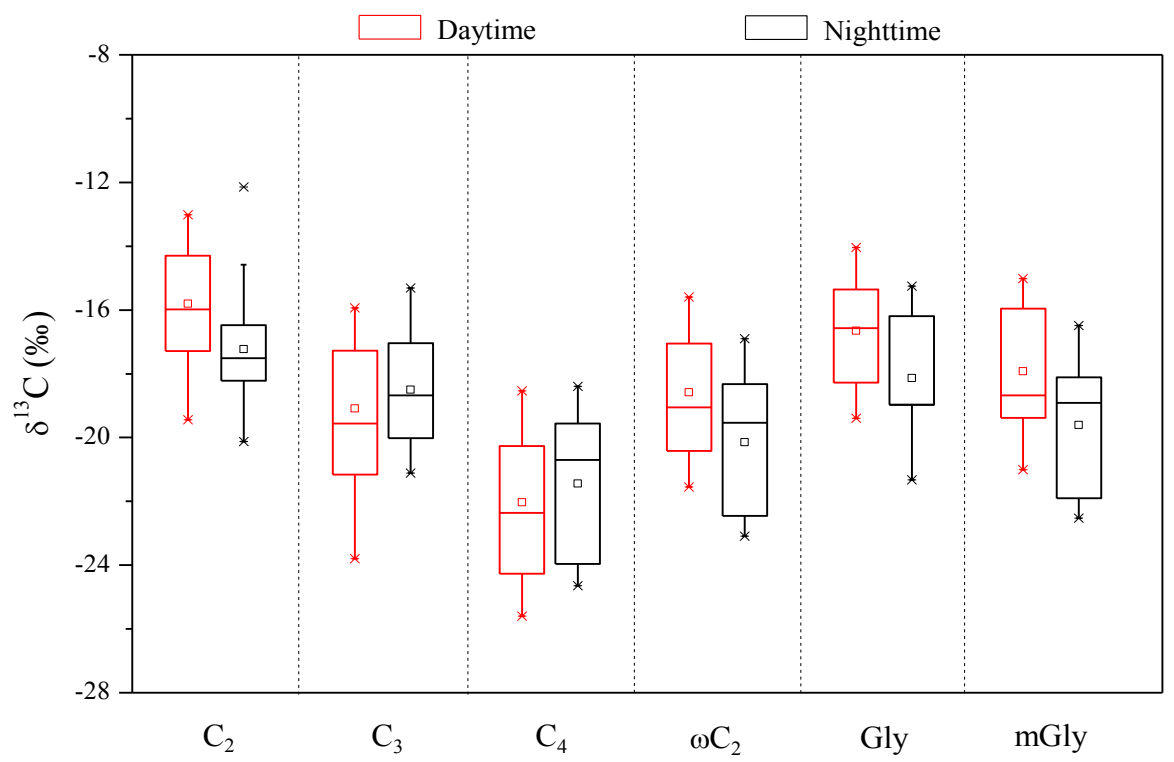

Figure 7. Diurnal variations of stable carbon isotope composition of low molecular weight dicarboxylic acids $\left(\mathrm{C}_{2}-\mathrm{C}_{4}\right)$, the smallest ketocarboxylic acids $\left(\omega \mathrm{C}_{2}\right)$ and $\alpha$-dicarbonyls (Gly, mGly) in $\mathrm{PM}_{2.5}$ collected at the summit of Mt. Tai during the summer.

\subsection{Stable carbon isotopic composition of oxalic acid and related $\mathrm{SOA}$}

To further understand the formation mechanisms of $\mathrm{C}_{2}$ and related SOA, the stable isotopic composition of major dicarboxylic acids and related SOA in the Mt. Tai aerosols was investigated (Table 5). Generally, an increase in $\delta^{13} \mathrm{C}$ values was observed, with a decrease in carbon numbers of dicarboxylic acids. The averaged $\delta^{13} \mathrm{C}$ value (daytime: $-15.8 \% \circ \pm 1.9 \%$; nighttime: $-17.2 \% \circ \pm 1.7 \%$ o) of $\mathrm{C}_{2}$ is higher than other dicarboxylic acids and related SOA in the Mt. Tai atmosphere, and also higher than those observed in urban regions such as Xi' an, China $(-22.7 \%$ o to $-22.0 \%$ o $)$ (Wang et al., 2012), and Sapporo, Japan (18.8 $\pm 2.0 \%$ ) (Aggarwal and Kawamura, 2008), and rural regions such as Morogoro, Tanzania (18.3\%o土1.7\%o) (Mkoma et al., 2014), but lower than those $(11.5 \% \circ \pm 2.8 \%$ ) (Zhang et al., 2016) at a background site (the Korea Climate Observatory at Gosan) in East Asia during the summer. Pavuluri et al. (2016) have reported that the average $\delta^{13} \mathrm{C}$ values of $\mathrm{C}_{2}$ from biogenic 

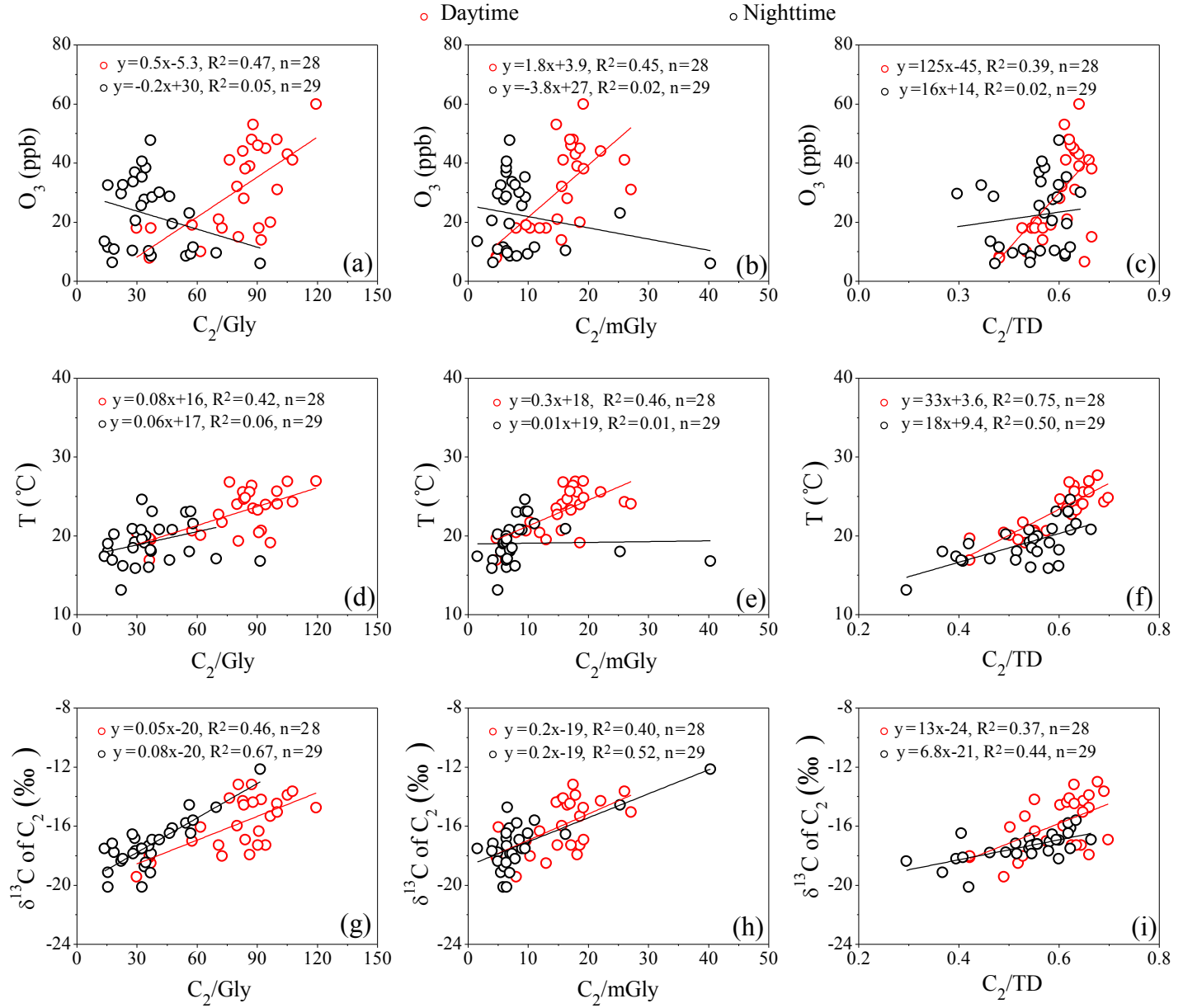

Figure 8. Correlation analysis for the mass ratios of $\mathrm{C}_{2} / \mathrm{Gly}, \mathrm{C}_{2} / \mathrm{mGly}$ and $\mathrm{C}_{2} / \mathrm{TD}$ with (a-c) concentrations of $\mathrm{O}_{3}$; (d-f) temperature and $(\mathrm{g}-\mathbf{i}) \delta^{13} \mathrm{C}$ of $\mathrm{C}_{2}$ during the daytime and nighttime ( $\mathrm{C}_{2} / \mathrm{TD}$ : mass ratio of oxalic acid to total dicarboxylic acids; $T$ : temperature).

aerosols are higher than those from anthropogenic aerosols. The relatively higher $\delta^{13} \mathrm{C}$ values of $\mathrm{C}_{2}$ observed at Mt. Tai further demonstrate that the contribution of biogenic sources to $\mathrm{C}_{2}$ and related SOA is more significant than anthropogenic sources, which is consistent with our discussions above. The average $\delta^{13} \mathrm{C}$ values of $\mathrm{C}_{4}$ are more negative than $\mathrm{C}_{2}$ and $\mathrm{C}_{3}$ (Fig. 7). Such a phenomenon is also observed in other regions (Aggarwal and Kawamura, 2008; Wang et al., 2012; Zhang et al., 2016). Photochemical decomposition (or breakdown) of longer chain dicarboxylic acids (e.g., $\mathrm{C}_{3}$ or $\mathrm{C}_{4}$ ) in the aerosol aqueous phase can form $\mathrm{C}_{2}$ (Wang et al., 2017), during which $\mathrm{C}_{3}$ or $\mathrm{C}_{4}$ release $\mathrm{CO}_{2} / \mathrm{CO}$ by reaction with $\mathrm{OH}$ radicals and other oxidants, resulting in $\mathrm{C}_{2}$ being more enriched in ${ }^{13} \mathrm{C}$ due to kinetic isotope effects (KIEs) (Wang et al., 2012). The ${ }^{13} \mathrm{C}$ enrichment in $\mathrm{C}_{2}$ is more distinguished in the daytime than in the nighttime (Table 5 and Fig. 7), largely due to the enhanced photochemical oxidation. However, such diurnal variation was not found for $\mathrm{C}_{3}$ and $\mathrm{C}_{4}$.

$\omega \mathrm{C}_{2}$ is an important intermediate of the aqueous-phase photochemical oxidation of precursors such as Gly, mGly and Pyr during the $\mathrm{C}_{2}$ formation process (Carlton et al., 2006; Fu et al., 2008). Thus, the higher mass ratios of $\mathrm{C}_{2} / \omega \mathrm{C}_{2}$, $\mathrm{C}_{2}$ / Gly and $\mathrm{C}_{2} / \mathrm{mGly}$ indicate that organic aerosols are more aged (Wang et al., 2017). As shown in Fig. $8 \mathrm{~g}-\mathrm{i}, \delta^{13} \mathrm{C}$ values of $\mathrm{C}_{2}$ correlate robustly with $\mathrm{C}_{2} / \mathrm{Gly}, \mathrm{C}_{2} / \mathrm{mGly}$ and $\mathrm{C}_{2}$ / total diacids, suggesting an enrichment of ${ }^{13} \mathrm{C}$ during the organic aerosol ageing process. During the campaign, $\omega \mathrm{C}_{2}$ is less enriched in ${ }^{13} \mathrm{C}$ in comparison with Gly, mGly and Pyr because the lighter isotope $\left({ }^{12} \mathrm{C}\right)$ is preferentially enriched in the products due to KIEs during the aqueousphase irreversible chemical reactions (Wang et al., 2012). As one of the major precursors of Gly, isoprene emitted directly from vegetation is depleted in ${ }^{13} \mathrm{C}$, with a range from $-32 \%$ o to $-27 \%$ (Affek and Yakir, 2003), but during the transport process, isoprene could gradually be enriched with ${ }^{13} \mathrm{C}\left(\delta^{13} \mathrm{C}\right.$ value $=-16.8 \%$ o $)$ due to isotope fractionation associated with the reaction with $\mathrm{OH}$ radicals (Rudolph et al., 2003). Moreover, chamber experiments have shown that $\beta$ pinene is preferably enriched with ${ }^{13} \mathrm{C}$ during its ozonolysis due to KIEs (Fisseha et al., 2009). Therefore, the $\delta^{13} \mathrm{C}$ val- 
ues of Gly and mGly are relatively higher than fresh BVOCs such as isoprene, largely attributed to the secondary formation from the oxidation of isoprene and other biogenic precursors.

\section{Summary and conclusions}

$\mathrm{PM}_{2.5}$ aerosols from the summit of Mt. Tai (1534 ma.s.1.) in the North China Plain during the summer of 2016 were analyzed for dicarboxylic acids, ketocarboxylic acids, $\alpha$ dicarbonyls, EC, OC and WSOC. Molecular compositions of dicarboxylic acids and related compounds in the forested highland region are similar to those on the ground and other mountainous regions. The concentrations of total dicarboxylic acids and ketocarboxylic acids are higher in the daytime than those in the daytime, but $\alpha$-dicarbonyls present lower values in the daytime, suggesting the mountainous atmospheric environment is more photochemically aged in the daytime than in the nighttime. The concentrations of oxalic acid and BSOA tracers and the mass ratios of $\mathrm{C}_{2} / \mathrm{Gly}$, $\mathrm{C}_{2} /$ mGly and $\mathrm{C}_{2}$ / total diacids correlate positively with $\mathrm{O}_{3}$ concentrations in the daytime during the campaign, but such correlations were not found at night. Moreover, $\mathrm{C}_{2}, \mathrm{C}_{2}$ / total diacids ratios and BSOA tracers correlate strongly with temperatures because higher temperature conditions can enhance the emissions of BVOCs and further promote the photochemical formation of $\mathrm{C}_{2} \cdot \mathrm{C}_{2}$ has a robust correlation with $\mathrm{pH}_{\mathrm{IS}}$ and $\mathrm{SO}_{4}^{2-}$ during the whole sampling period, indicating that acidic conditions can favor the formation of oxalic acid in the aqueous phase.

A significant enrichment of ${ }^{13} \mathrm{C}$ in dicarboxylic acids was observed as a function of their carbon number. The observed larger $\delta^{13} \mathrm{C}$ values of lower carbon numbered dicarboxylic acids can be explained by isotopic fractionations resulting from the atmospheric decomposition of relatively longer chain diacids or their precursors. Increased $\delta^{13} \mathrm{C}$ values of $C_{2}$ relative to $C_{2}$ / Gly and $C_{2}$ / mGly ratios also suggested an important effect of photochemical aging on the stable carbon isotopic composition of dicarboxylic acids.

Data availability. The data for this paper are available upon request from the corresponding author (wanggh@ieecas.cn).

Supplement. The supplement related to this article is available online at: https://doi.org/10.5194/acp-18-15069-2018-supplement.

Author contributions. GW designed and supervised the whole project. ZH collected the aerosol samples. JM and XL conducted the experiments. JM performed the data analyses and wrote the manuscript. All authors contributed to the paper with useful scientific discussions or comments.
Competing interests. The authors declare that they have no conflict of interest.

Special issue statement. This article is part of the special issue "Regional transport and transformation of air pollution in eastern China". It is not associated with a conference.

Acknowledgements. This work was supported by China National Science Funds (grant no. 41505112 and 41773117), the Natural Science Foundation of Shandong Province (grant no. BS2015HZ002), the China National Natural Science Funds for Distinguished Young Scholars (no. 41325014) and Open Funds of the State Key Laboratory of Loess and Quaternary Geology, Institute of Earth Environment, Chinese Academy of Sciences (grant nos. SKLLQG1509 and SKLLQG1504).

Edited by: Yuan Wang

Reviewed by: four anonymous referees

\section{References}

Affek, H. P. and Yakir, D.: Natural Abundance Carbon Isotope Composition of Isoprene Reflects Incomplete Coupling between Isoprene Synthesis and Photosynthetic Carbon Flow, Plant Physiol., 131, 1727-1736, 2003.

Aggarwal, S. G. and Kawamura, K.: Molecular distributions and stable carbon isotopic compositions of dicarboxylic acids and related compounds in aerosols from Sapporo, Japan: Implications for photochemical aging during longrange atmospheric transport, J. Geophys. Res., 113, D14301, https://doi.org/10.1029/2007jd009365, 2008.

Bian, Q., Huang, X. H. H., and Yu, J. Z.: One-year observations of size distribution characteristics of major aerosol constituents at a coastal receptor site in Hong Kong - Part 1: Inorganic ions and oxalate, Atmos. Chem. Phys., 14, 9013-9027, https://doi.org/10.5194/acp-14-9013-2014, 2014.

Bikkina, S., Kawamura, K., and Sarin, M.: Secondary Organic Aerosol Formation over Coastal Ocean: Inferences from Atmospheric Water-Soluble Low Molecular Weight Organic Compounds, Environ. Sci. Technol., 51, 4347-4357, https://doi.org/10.1021/acs.est.6b05986, 2017.

Bilde, M., Barsanti, K., Booth, M., Cappa, C. D., Donahue, N. M., Emanuelsson, E. U., McFiggans, G., Krieger, U. K., Marcolli, C., Topping, D., Ziemann, P., Barley, M., Clegg, S., Dennis-Smither, B., Hallquist, M., Hallquist, Å. M., Khlystov, A., Kulmala, M., Mogensen, D., Percival, C. J., Pope, F., Reid, J. P., Ribeiro da Silva, M. A. V., Rosenoern, T., Salo, K., Soonsin, V. P., Yli-Juuti, T., Prisle, N. L., Pagels, J., Rarey, J., Zardini, A. A., and Riipinen, I.: Saturation Vapor Pressures and Transition Enthalpies of Low-Volatility Organic Molecules of Atmospheric Relevance: From Dicarboxylic Acids to Complex Mixtures, Chem. Rev., 115, 4115-4156, https://doi.org/10.1021/cr5005502, 2015.

Boreddy, S. K. R., Kawamura, K., and Tachibana, E.: Long-term (2001-2013) observations of water-soluble dicarboxylic acids and related compounds over the western North Pacific: trends, 
seasonality and source apportionment, Sci. Rep.-UK, 7, 8518, https://doi.org/10.1038/s41598-017-08745-w, 2017.

Carlton, A. G., Turpin, B. J., Lim, H.-J., Altieri, K. E., and Seitzinger, S.: Link between isoprene and secondary organic aerosol (SOA): Pyruvic acid oxidation yields low volatility organic acids in clouds, Geophys. Res. Lett., 33, L06822, https://doi.org/10.1029/2005g1025374, 2006.

Carlton, A. G., Turpin, B. J., Altieri, K. E., Seitzinger, S., Reff, A., Lim, H.-J., and Ervens, B.: Atmospheric oxalic acid and SOA production from glyoxal: Results of aqueous photooxidation experiments, Atmos. Environ., 41, 7588-7602, https://doi.org/10.1016/j.atmosenv.2007.05.035, 2007.

Cheng, C., Wang, G., Zhou, B., Meng, J., Li, J., Cao, J., and Xiao, S.: Comparison of dicarboxylic acids and related compounds in aerosol samples collected in Xi'an, China during haze and clean periods, Atmos. Environ., 81, 443-449, https://doi.org/10.1016/j.atmosenv.2013.09.013, 2013.

Cheng, C., Wang, G., Meng, J., Wang, Q., Cao, J., Li, J., and Wang, J.: Size-resolved airborne particulate oxalic and related secondary organic aerosol species in the urban atmosphere of Chengdu, China, Atmos. Res., 161-162, 134-142, https://doi.org/10.1016/j.atmosres.2015.04.010, 2015.

Cheng, C., Li, M., Chan, C. K., Tong, H., Chen, C., Chen, D., Wu, D., Li, L., Wu, C., Cheng, P., Gao, W., Huang, Z., Li, X., Zhang, Z., Fu, Z., Bi, Y., and Zhou, Z.: Mixing state of oxalic acid containing particles in the rural area of Pearl River Delta, China: implications for the formation mechanism of oxalic acid, Atmos. Chem. Phys., 17, 9519-9533, https://doi.org/10.5194/acp17-9519-2017, 2017.

Chow, J. C., Watson, J. G., Chen, L. W. A., Arnott, W. P., Moosmüller, H., and Fung, K.: Equivalence of Elemental Carbon by Thermal/Optical Reflectance and Transmittance with Different Temperature Protocols, Environ. Sci. Technol., 38, 4414-4422, https://doi.org/10.1021/es034936u, 2004.

Claeys, M., Graham, B., Vas, G., Wang, W., Vermeylen, R., Pashynska, V., Cafmeyer, J., Guyon, P., Andreae, M. O., Artaxo, P., and Maenhaut, W.: Formation of Secondary Organic Aerosols Through Photooxidation of Isoprene, Science, 303, 1173-1176, https://doi.org/10.1126/science.1092805, 2004.

Clegg, S. L., Brimblecombe, P., and Wexler, A. S.: Thermodynamic Model of the System $\mathrm{H}^{+}-\mathrm{NH}_{4}^{+}-\mathrm{SO}_{4}^{2-}-\mathrm{NO}_{3}^{-}-\mathrm{H}_{2} \mathrm{O}$ at Tropospheric Temperatures, J. Phys. Chem. A, 102, 2137-2154, https://doi.org/10.1021/jp973042r, 1998.

Deshmukh, D. K., Kawamura, K., Deb, M. K., and Boreddy, S. K. R.: Sources and formation processes of water-soluble dicarboxylic acids, $\omega$-oxocarboxylic acids, $\alpha$-dicarbonyls, and major ions in summer aerosols from eastern central India, J. Geophys. Res.-Atmos., 122, 3630-3652, https://doi.org/10.1002/2016jd026246, 2017.

Edwards, P. M., Aikin, K. C., Dube, W. P., Fry, J. L., Gilman, J. B., de Gouw, J. A., Graus, M. G., Hanisco, T. F., Holloway, J., Huber, G., Kaiser, J., Keutsch, F. N., Lerner, B. M., Neuman, J. A., Parrish, D. D., Peischl, J., Pollack, I. B., Ravishankara, A. R., Roberts, J. M., Ryerson, T. B., Trainer, M., Veres, P. R., Wolfe, G. M., Warneke, C., and Brown, S. S.: Transition from high- to low-NOx control of night-time oxidation in the southeastern US, Nature Geoscience, 10, 490-496, 2017.

Ehn, M., Thornton, J. A., Kleist, E., Sipilä, M., Junninen, H., Pullinen, I., Springer, M., Rubach, F., Tillmann, R., Lee, B.,
Lopez-Hilfiker, F., Andres, S., Acir, I.-H., Rissanen, M., Jokinen, T., Schobesberger, S., Kangasluoma, J., Kontkanen, J., Nieminen, T., Kurtén, T., Nielsen, L. B., Jørgensen, S., Kjaergaard, H. G., Canagaratna, M., Maso, M. D., Berndt, T., Petäjä, T., Wahner, A., Kerminen, V.-M., Kulmala, M., Worsnop, D. R., Wildt, J., and Mentel, T. F.: A large source of lowvolatility secondary organic aerosol, Nature, 506, 476-479, https://doi.org/10.1038/nature13032, 2014.

Ervens, B., Sorooshian, A., Lim, Y. B., and Turpin, B. J.: Key parameters controlling $\mathrm{OH}$-initiated formation of secondary organic aerosol in the aqueous phase (aqSOA), J. Geophys. Res.Atmos., 119, 3997-4016, https://doi.org/10.1002/2013jd021021, 2014.

Fick, J., Pommer, L., Nilsson, C., and Andersson, B.: Effect of OH radicals, relative humidity, and time on the composition of the products formed in the ozonolysis of $\alpha$-pinene, Atmos. Environ., 37, 4087-4096, https://doi.org/10.1016/S1352-2310(03)005223, 2003.

Fisseha, R., Spahn, H., Wegener, R., Hohaus, T., Brasse, G., Wissel, H., Tillmann, R., Wahner, A., Koppmann, R., and KiendlerScharr, A.: Stable carbon isotope composition of secondary organic aerosol from $\beta$-pinene oxidation, J. Geophys. Res.-Atmos., 114, D02304, https://doi.org/10.1029/2008jd011326, 2009.

Fountoukis, C. and Nenes, A.: ISORROPIA II: a computationally efficient thermodynamic equilibrium model for $\mathrm{K}^{+}-\mathrm{Ca}^{2+}-$ $\mathrm{Mg}^{2+}-\mathrm{NH}_{4}^{+}-\mathrm{Na}^{+}-\mathrm{SO}_{4}^{2-}-\mathrm{NO}_{3}^{-}-\mathrm{Cl}^{-}-\mathrm{H}_{2} \mathrm{O}$ aerosols, Atmos. Chem. Phys., 7, 4639-4659, https://doi.org/10.5194/acp-74639-2007, 2007.

Fu, P., Kawamura, K., Kanaya, Y., and Wang, Z.: Contributions of biogenic volatile organic compounds to the formation of secondary organic aerosols over Mt. Tai, Central East China, Atmos. Environ., 44, 4817-4826, https://doi.org/10.1016/j.atmosenv.2010.08.040, 2010.

Fu, P., Kawamura, K., Usukura, K., and Miura, K.: Dicarboxylic acids, ketocarboxylic acids and glyoxal in the marine aerosols collected during a round-the-world cruise, Mar. Chem., 148, 2232, https://doi.org/10.1016/j.marchem.2012.11.002, 2013.

Fu, T.-M., Jacob, D. J., Wittrock, F., Burrows, J. P., Vrekoussis, M., and Henze, D. K.: Global budgets of atmospheric glyoxal and methylglyoxal, and implications for formation of secondary organic aerosols, J. Geophys. Res., 113, D15303, https://doi.org/10.1029/2007jd009505, 2008.

Gao, S., Ng, N. L., Keywood, M., Varutbangkul, V., Bahreini, R., Nenes, A., He, J., Yoo, K. Y., Beauchamp, J. L., Hodyss, R. P., Flagan, R. C., and Seinfeld, J. H.: Particle Phase Acidity and Oligomer Formation in Secondary Organic Aerosol, Environ. Sci. Technol., 38, 6582-6589, https://doi.org/10.1021/es049125k, 2004.

Hallquist, M., Wenger, J. C., Baltensperger, U., Rudich, Y., Simpson, D., Claeys, M., Dommen, J., Donahue, N. M., George, C., Goldstein, A. H., Hamilton, J. F., Herrmann, H., Hoffmann, T., Iinuma, Y., Jang, M., Jenkin, M. E., Jimenez, J. L., Kiendler-Scharr, A., Maenhaut, W., McFiggans, G., Mentel, Th. F., Monod, A., Prévôt, A. S. H., Seinfeld, J. H., Surratt, J. D., Szmigielski, R., and Wildt, J.: The formation, properties and impact of secondary organic aerosol: current and emerging issues, Atmos. Chem. Phys., 9, 5155-5236, https://doi.org/10.5194/acp9-5155-2009, 2009. 
Hatakeyama, S., Ohno, M., Weng, J., Takagi, H., and Akimoto, H.: Mechanism for the formation of gaseous and particulate products from ozone-cycloalkene reactions in air, Environ. Sci. Technol., 21, 52-57, https://doi.org/10.1021/es00155a005, 1987.

He, N., Kawamura, K., Okuzawa, K., Pochanart, P., Liu, Y., Kanaya, Y., and Wang, Z. F.: Diurnal and temporal variations of watersoluble dicarboxylic acids and related compounds in aerosols from the northern vicinity of Beijing: Implication for photochemical aging during atmospheric transport, Sci. Total Environ., 499, 154-165, https://doi.org/10.1016/j.scitotenv.2014.08.050, 2014.

Hegde, P. and Kawamura, K.: Seasonal variations of watersoluble organic carbon, dicarboxylic acids, ketocarboxylic acids, and a-dicarbonyls in Central Himalayan aerosols, Atmos. Chem. Phys., 12, 6645-6665, https://doi.org/10.5194/acp-126645-2012, 2012.

Herrmann, H., Ervens, B., Nowacki, P., Wolke, R., and Zellner, R.: A chemical aqueous phase radical mechanism for tropospheric chemistry, Chemosphere, 38, 1223-1232, https://doi.org/10.1016/S0045-6535(98)00520-7, 1999.

Ho, K. F., Cao, J. J., Lee, S. C., Kawamura, K., Zhang, R. J., Chow, J. C., and Watson, J. G.: Dicarboxylic acids, ketocarboxylic acids, and dicarbonyls in the urban atmosphere of China, J. Geophys. Res.-Atmos., 112, D22S27, https://doi.org/10.1029/2006jd008011, 2007.

Hoque, M. M. M., Kawamura, K., and Uematsu, M.: Spatiotemporal distributions of dicarboxylic acids, $\omega$-oxocarboxylic acids, pyruvic acid, $\alpha$-dicarbonyls and fatty acids in the marine aerosols from the North and South Pacific, Atmos. Res., 185, 158-168, https://doi.org/10.1016/j.atmosres.2016.10.022, 2017.

Huang, D., Zhang, X., Chen, Z. M., Zhao, Y., and Shen, X. L.: The kinetics and mechanism of an aqueous phase isoprene reaction with hydroxyl radical, Atmos. Chem. Phys., 11, 7399-7415, https://doi.org/10.5194/acp-11-7399-2011, 2011.

Jung, J., Tsatsral, B., Kim, Y. J., and Kawamura, K.: Organic and inorganic aerosol compositions in Ulaanbaatar, Mongolia, during the cold winter of 2007 to 2008: Dicarboxylic acids, ketocarboxylic acids, and $\alpha$-dicarbonyls, J. Geophys. Res.-Atmos., 115, D22203, https://doi.org/10.1029/2010jd014339, 2010.

Kawamura, K. and Bikkina, S.: A review of dicarboxylic acids and related compounds in atmospheric aerosols: Molecular distributions, sources and transformation, Atmos. Res., 170, 140-160, https://doi.org/10.1016/j.atmosres.2015.11.018, 2016.

Kawamura, K. and Ikushima, K.: Seasonal changes in the distribution of dicarboxylic acids in the urban atmosphere, Environ. Sci. Technol., 27, 2227-2235, https://doi.org/10.1021/es00047a033, 1993.

Kawamura, K. and Kaplan, I. R.: Motor exhaust emissions as a primary source for dicarboxylic acids in Los Angeles ambient air, Environ. Sci. Technol., 21, 105-110, https://doi.org/10.1021/es00155a014, 1987.

Kawamura, K. and Usukura, K.: Distributions of low molecular weight dicarboxylic acids in the North Pacific aerosol samples, J. Oceanogr., 49, 271-283, https://doi.org/10.1007/bf02269565, 1993.

Kawamura, K., Kasukabe, H., and Barrie, L. A.: Source and reaction pathways of dicarboxylic acids, ketoacids and dicarbonyls in arctic aerosols: One year of observations, Atmos. Environ., 30, 1709-1722, https://doi.org/10.1016/1352-2310(95)00395-9, 1996.
Kawamura, K. and Watanabe, T.: Determination of Stable Carbon Isotopic Compositions of Low Molecular Weight Dicarboxylic Acids and Ketocarboxylic Acids in Atmospheric Aerosol and Snow Samples, Anal. Chem., 76, 5762-5768, https://doi.org/10.1021/ac049491m, 2004.

Kawamura, K., Okuzawa, K., Aggarwal, S. G., Irie, H., Kanaya, Y., and Wang, Z.: Determination of gaseous and particulate carbonyls (glycolaldehyde, hydroxyacetone, glyoxal, methylglyoxal, nonanal and decanal) in the atmosphere at Mt. Tai, Atmos. Chem. Phys., 13, 5369-5380, https://doi.org/10.5194/acp13-5369-2013, 2013a.

Kawamura, K., Tachibana, E., Okuzawa, K., Aggarwal, S. G., Kanaya, Y., and Wang, Z. F.: High abundances of water-soluble dicarboxylic acids, ketocarboxylic acids and a-dicarbonyls in the mountaintop aerosols over the North China Plain during wheat burning season, Atmos. Chem. Phys., 13, 8285-8302, https://doi.org/10.5194/acp-13-8285-2013, 2013 b.

Kroll, J. H. and Seinfeld, J. H.: Chemistry of secondary organic aerosol: Formation and evolution of low-volatility organics in the atmosphere, Atmos. Environ., 42, 3593-3624, https://doi.org/10.1016/j.atmosenv.2008.01.003, 2008.

Kundu, S., Kawamura, K., Andreae, T. W., Hoffer, A., and Andreae, M. O.: Diurnal variation in the water-soluble inorganic ions, organic carbon and isotopic compositions of total carbon and nitrogen in biomass burning aerosols from the LBA-SMOCC campaign in Rondônia, Brazil, J. Aerosol Sci., 41, 118-133, https://doi.org/10.1016/j.jaerosci.2009.08.006, 2010.

Kunwar, B., Torii, K., and Kawamura, K.: Springtime influences of Asian outflow and photochemistry on the distributions of diacids, oxoacids and $\alpha$-dicarbonyls in the aerosols from the western North Pacific Rim, Tellus B, 69, 1369341, https://doi.org/10.1080/16000889.2017.1369341, 2017.

Leaitch, W. R., Li, S. M., Liu, P. S. K., Banic, C. M., Macdonald, A. M., Isaac, G. A., Couture, M. D., and Strapp, J. W.: Relationships among ccn, aerosol size distribution and ion chemistry from airborne measurements over the bay of fundy in august-september, 1995 A2 - Kulmala, Markku, in: Nucleation and Atmospheric Aerosols 1996, edited by: Wagner, P. E., Pergamon, Amsterdam, 840-843, 1996.

Lee, A., Goldstein, A. H., Kroll, J. H., Ng, N. L., Varutbangkul, V., Flagan, R. C., and Seinfeld, J. H.: Gas-phase products and secondary aerosol yields from the photooxidation of 16 different terpenes, J. Geophys. Res.-Atmos., 111, D17305, https://doi.org/10.1029/2006jd007050, 2006.

Li, J. J., Wang, G. H., Cao, J. J., Wang, X. M., and Zhang, R. J.: Observation of biogenic secondary organic aerosols in the atmosphere of a mountain site in central China: temperature and relative humidity effects, Atmos. Chem. Phys., 13, 11535-11549, https://doi.org/10.5194/acp-13-11535-2013, 2013.

Lim, H.-J., Carlton, A. G., and Turpin, B. J.: Isoprene Forms Secondary Organic Aerosol through Cloud Processing:? Model Simulations, Environ. Sci. Technol., 39, 4441-4446, https://doi.org/10.1021/es048039h, 2005.

McNeill, V. F.: Aqueous Organic Chemistry in the Atmosphere: Sources and Chemical Processing of Organic Aerosols, Environ. Sci. Technol., 49, 1237-1244, https://doi.org/10.1021/es5043707, 2015.

Meng, J., Wang, G., Li, J., Cheng, C., and Cao, J.: Atmospheric oxalic acid and related secondary organic aerosols in Qinghai Lake, 
a continental background site in Tibet Plateau, Atmos. Environ., 79, 582-589, https://doi.org/10.1016/j.atmosenv.2013.07.024, 2013.

Meng, J., Wang, G., Li, J., Cheng, C., Ren, Y., Huang, Y., Cheng, Y., Cao, J., and Zhang, T.: Seasonal characteristics of oxalic acid and related SOA in the free troposphere of Mt. Hua, central China: Implications for sources and formation mechanisms, Sci. Total Environ., 493, 1088-1097, https://doi.org/10.1016/j.scitotenv.2014.04.086, 2014.

Miyazaki, Y., Aggarwal, S. G., Singh, K., Gupta, P. K., and Kawamura, K.: Dicarboxylic acids and water-soluble organic carbon in aerosols in New Delhi, India, in winter: Characteristics and formation processes, J. Geophys. Res.-Atmos., 114, D19206, https://doi.org/10.1029/2009jd011790, 2009.

Mkoma, S. L., Kawamura, K., and Tachibana, E.: Stable carbon isotopic compositions of low-molecular-weight dicarboxylic acids, glyoxylic acid and glyoxal in tropical aerosols: implications for photochemical processes of organic aerosols, Tellus B, 66, 23702, https://doi.org/10.3402/tellusb.v66.23702, 2014.

Mochizuki, T., Kawamura, K., Miyazaki, Y., Wada, R., Takahashi, Y., Saigusa, N., and Tani, A.: Secondary formation of oxalic acid and related organic species from biogenic sources in a larch forest at the northern slope of Mt. Fuji, Atmos. Environ., 166, 255262, https://doi.org/10.1016/j.atmosenv.2017.07.028, 2017.

Myriokefalitakis, S., Tsigaridis, K., Mihalopoulos, N., Sciare, J., Nenes, A., Kawamura, K., Segers, A., and Kanakidou, M.: In-cloud oxalate formation in the global troposphere: a 3-D modeling study, Atmos. Chem. Phys., 11, 5761-5782, https://doi.org/10.5194/acp-11-5761-2011, 2011.

Narukawa, M., Kawamura, K., Takeuchi, N., and Nakajima, T.: Distribution of dicarboxylic acids and carbon isotopic compositions in aerosols from 1997 Indonesian forest fires, Geophys. Res. Lett., 26, 3101-3104, https://doi.org/10.1029/1999gl010810, 1999.

Pathak, R. K., Wu, W. S., and Wang, T.: Summertime $\mathrm{PM}_{2.5}$ ionic species in four major cities of China: nitrate formation in an ammonia-deficient atmosphere, Atmos. Chem. Phys., 9, 17111722, https://doi.org/10.5194/acp-9-1711-2009, 2009.

Pavuluri, C. M., Kawamura, K., and Swaminathan, T.: Watersoluble organic carbon, dicarboxylic acids, ketoacids, and $\alpha$ dicarbonyls in the tropical Indian aerosols, J. Geophys. Res.Atmos., 115, D11302, https://doi.org/10.1029/2009jd012661, 2010.

Pavuluri, C. M. and Kawamura, K.: Enrichment of (13)C in diacids and related compounds during photochemical processing of aqueous aerosols: New proxy for organic aerosols aging, Sci. Rep.-UK, 6, 36467, https://doi.org/10.1038/srep36467, 2016.

Rapf, R. J., Dooley, M. R., Kappes, K., Perkins, R. J., and Vaida, V.: $\mathrm{pH}$ Dependence of the Aqueous Photochemistry of $\alpha$-Keto Acids, J. Phys. Chem.A, 121, 8368-8379, https://doi.org/10.1021/acs.jpca.7b08192, 2017.

Rudolph, J., Anderson, R. S., Czapiewski, K. V., Czuba, E., Ernst, D., Gillespie, T., Huang, L., Rigby, C., and Thompson, A. E.: The Stable Carbon Isotope Ratio of Biogenic Emissions of Isoprene and the Potential Use of Stable Isotope Ratio Measurements to Study Photochemical Processing of Isoprene in the Atmosphere, J. Atmos. Chem., 44, 39-55, https://doi.org/10.1023/a:1022116304550, 2003.
Sorooshian, A., Lu, M.-L., Brechtel, F. J., Jonsson, H., Feingold, G., Flagan, R. C., and Seinfeld, J. H.: On the Source of Organic Acid Aerosol Layers above Clouds, Environ. Sci. Technol., 41, 4647-4654, https://doi.org/10.1021/es0630442, 2007a.

Sorooshian, A., Ng, N. L., Chan, A. W. H., Feingold, G., Flagan, R. C., and Seinfeld, J. H.: Particulate organic acids and overall water-soluble aerosol composition measurements from the 2006 Gulf of Mexico Atmospheric Composition and Climate Study (GoMACCS), J. Geophys. Res., 112, D13201, https://doi.org/10.1029/2007jd008537, 2007b.

Surratt, J. D., Lewandowski, M., Offenberg, J. H., Jaoui, M., Kleindienst, T. E., Edney, E. O., and Seinfeld, J. H.: Effect of Acidity on Secondary Organic Aerosol Formation from Isoprene, Environ. Sci. Technol., 41, 5363-5369, https://doi.org/10.1021/es0704176, 2007.

Surratt, J. D., Chan, A. W. H., Eddingsaas, N. C., Chan, M., Loza, C. L., Kwan, A. J., Hersey, S. P., Flagan, R. C., Wennberg, P. O., and Seinfeld, J. H.: Reactive intermediates revealed in secondary organic aerosol formation from isoprene, P. Natl. Acad. Sci. USA, 107, 6640-6645, https://doi.org/10.1073/pnas.0911114107, 2010.

Tan, Y., Carlton, A. G., Seitzinger, S. P., and Turpin, B. J.: SOA from methylglyoxal in clouds and wet aerosols: Measurement and prediction of key products, Atmos. Environ., 44, 5218-5226, https://doi.org/10.1016/j.atmosenv.2010.08.045, 2010.

Wang, G., Kawamura, K., Umemoto, N., Xie, M., Hu, S., and Wang, Z.: Water-soluble organic compounds in $\mathrm{PM}_{2.5}$ and size-segregated aerosols over Mount Tai in North China Plain, J. Geophys. Res.-Atmos., 114, D19208, https://doi.org/10.1029/2008jd011390, 2009.

Wang, G., Xie, M., Hu, S., Gao, S., Tachibana, E., and Kawamura, K.: Dicarboxylic acids, metals and isotopic compositions of $\mathrm{C}$ and $\mathrm{N}$ in atmospheric aerosols from inland China: implications for dust and coal burning emission and secondary aerosol formation, Atmos. Chem. Phys., 10, 6087-6096, https://doi.org/10.5194/acp-10-6087-2010, 2010.

Wang, G., Kawamura, K., Cheng, C., Li, J., Cao, J., Zhang, R., Zhang, T., Liu, S., and Zhao, Z.: Molecular Distribution and Stable Carbon Isotopic Composition of Dicarboxylic Acids, Ketocarboxylic Acids, and $\alpha$-Dicarbonyls in Size-Resolved Atmospheric Particles From Xi' an City, China, Environ. Sci. Technol., 46, 4783-4791, https://doi.org/10.1021/es204322c, 2012.

Wang, G., Cheng, C., Meng, J., Huang, Y., Li, J., and Ren, Y.: Field observation on secondary organic aerosols during Asian dust storm periods: Formation mechanism of oxalic acid and related compounds on dust surface, Atmos. Environ., 113, 169176, https://doi.org/10.1016/j.atmosenv.2015.05.013, 2015.

Wang, G., Zhang, F., Peng, J., Duan, L., Ji, Y., Marrero-Ortiz, W., Wang, J., Li, J., Wu, C., Cao, C., Wang, Y., Zheng, J., Secrest, J., Li, Y., Wang, Y., Li, H., Li, N., and Zhang, R.: Particle acidity and sulfate production during severe haze events in China cannot be reliably inferred by assuming a mixture of inorganic salts, Atmos. Chem. Phys., 18, 10123-10132, https://doi.org/10.5194/acp-18-10123-2018, 2018.

Wang, G., Zhang, R., Gomez, M. E., Yang, L., Levy Zamora, M., Hu, M., Lin, Y., Peng, J., Guo, S., Meng, J., Li, J., Cheng, C., Hu, T., Ren, Y., Wang, Y., Gao, J., Cao, J., An, Z., Zhou, W., Li, G., Wang, J., Tian, P., Marrero-Ortiz, W., Secrest, J., Du, Z., Zheng, J., Shang, D., Zeng, L., Shao, M., Wang, W., Huang, Y., 
Wang, Y., Zhu, Y., Li, Y., Hu, J., Pan, B., Cai, L., Cheng, Y., Ji, Y., Zhang, F., Rosenfeld, D., Liss, P. S., Duce, R. A., Kolb, C. E., and Molina, M. J.: Persistent sulfate formation from London Fog to Chinese haze, P. Natl. Acad. Sci. USA, 113, 13630-13635, https://doi.org/10.1073/pnas.1616540113, 2016.

Wang, J., Wang, G., Gao, J., Wang, H., Ren, Y., Li, J., Zhou, B., Wu, C., Zhang, L., Wang, S., and Chai, F.: Concentrations and stable carbon isotope compositions of oxalic acid and related SOA in Beijing before, during, and after the 2014 APEC, Atmos. Chem. Phys., 17, 981-992, https://doi.org/10.5194/acp-17981-2017, 2017.

Warneck, P.: In-cloud chemistry opens pathway to the formation of oxalic acid in the marine atmosphere, Atmos. Environ., 37, 24232427, https://doi.org/10.1016/S1352-2310(03)00136-5, 2003.

Yang, X., Xue, L., Yao, L., Li, Q., Wen, L., Zhu, Y., Chen, T., Wang, X., Yang, L., Wang, T., Lee, S., Chen, J., and Wang, W.: Carbonyl compounds at Mount Tai in the North China Plain: Characteristics, sources, and effects on ozone formation, Atmos. Res., 196, 53-61, https://doi.org/10.1016/j.atmosres.2017.06.005, 2017.

Yu, J. Z., Huang, X.-F., Xu, J., and Hu, M.: When Aerosol Sulfate Goes Up, So Does Oxalate?: Implication for the Formation Mechanisms of Oxalate, Environ. Sci. Technol., 39, 128-133, https://doi.org/10.1021/es049559f, 2005.

Zhang, H., Surratt, J. D., Lin, Y. H., Bapat, J., and Kamens, R. M.: Effect of relative humidity on SOA formation from isoprene/NO photooxidation: enhancement of 2-methylglyceric acid and its corresponding oligoesters under dry conditions, Atmos. Chem. Phys., 11, 6411-6424, https://doi.org/10.5194/acp11-6411-2011, 2011.
Zhang, R., Wang, G., Guo, S., Zamora, M. L., Ying, Q., Lin, Y., Wang, W., Hu, M., and Wang, Y.: Formation of urban fine particulate matter, Chem. Rev., 115, 3803-3855, https://doi.org/10.1021/acs.chemrev.3805b00067, 2015.

Zhang, Y.-L., Kawamura, K., Cao, F., and Lee, M.: Stable carbon isotopic compositions of low-molecular-weight dicarboxylic acids, oxocarboxylic acids, $\alpha$-dicarbonyls, and fatty acids: Implications for atmospheric processing of organic aerosols, J. Geophys. Res.-Atmos., 121, 3707-3717, https://doi.org/10.1002/2015jd024081, 2016.

Zhao, W., Kawamura, K., Yue, S., Wei, L., Ren, H., Yan, Y., Kang, M., Li, L., Ren, L., Lai, S., Li, J., Sun, Y., Wang, Z., and $\mathrm{Fu}$, P.: Molecular distribution and compound-specific stable carbon isotopic composition of dicarboxylic acids, oxocarboxylic acids and $\alpha$-dicarbonyls in $\mathrm{PM}_{2.5}$ from Beijing, China, Atmos. Chem. Phys., 18, 2749-2767, https://doi.org/10.5194/acp18-2749-2018, 2018.

Zhu, Y., Yang, L., Chen, J., Kawamura, K., Sato, M., Tilgner, A., van Pinxteren, D., Chen, Y., Xue, L., Wang, X., Simpson, I. J., Herrmann, H., Blake, D. R., and Wang, W.: Molecular distributions of dicarboxylic acids, oxocarboxylic acids and $\alpha$ dicarbonyls in PM2.5 collected at the top of Mt. Tai, North China, during the wheat burning season of 2014, Atmos. Chem. Phys., 18, 10741-10758, https://doi.org/10.5194/acp-18-107412018, 2018. 